\title{
MAINTAINING THE TEMPORARY NATURE OF THE SEASONAL AGRICULTURE WORKERS PROGRAM IN CANADA: A SOURCE COUNTRY ANALYSIS
}

\author{
by \\ Deon Castello \\ BA (Hons), UOIT, 2016 \\ MA, McMaster University, 2018 \\ A Major Research Paper \\ presented to Ryerson University \\ in partial fulfilment of the \\ requirements for the degree of \\ Master of Arts \\ in the program of \\ Immigration and Settlement Studies
}

Toronto, Ontario, Canada, 2019

(C) Deon Castello, 2019 


\section{AUTHOR'S DECLARATION FOR ELECTRONIC SUBMISSION OF A MRP}

I hereby declare that I am the sole author of this MRP. This is a true copy of the MRP, including any required final revisions.

I authorize Ryerson University to lend this MRP to other institutions or individuals for the purpose of scholarly research.

I further authorize Ryerson University to reproduce this MRP by photocopying or by other means, in total or in part, at the request of other institutions or individuals for the purpose of scholarly research.

I understand that my MRP may be made electronically available to the public. 


\title{
MAINTAINING THE TEMPORARY NATURE OF THE SEASONAL AGRICULTURE WORKERS PROGRAM IN CANADA: A SOURCE COUNTRY ANALYSIS
}

\author{
(C) Deon Castello, 2019 \\ Master of Arts \\ Immigration and Settlement Studies \\ Ryerson University
}

\begin{abstract}
The successful management of the Seasonal Agricultural Worker Program (SAWP) in Canada for the past 52 years lies with the bilateral agreement of the program's Memorandum of Understanding. Despite its expansion over the decades, the program does not offer a pathway to permanent residency for migrant farm-workers. The power imbalance in maintaining the ability to grant permanent residence pathways lies mainly with the host country (Canada). However, source country by proxy also appears to play a role in maintaining the temporary nature of the program via managing and policing the SAWP workers. Based on a case study, St. Vincent and the Grenadines, and a total of 10 interviews with workers, former workers, former and current civil servants responsible for the program in this country, the Major Research Paper interrogates the roles played by the source country in the continuation of the temporary migrant status and conditions associated with SAWP.
\end{abstract}

Key words: seasonal agricultural worker program, labour migration, temporary foreign worker, migrant farm worker. 


\section{ACKNOWLEDGMENTS}

Dr. Sedef Arat-Koç, words are not enough to thank you for your patience, guidance, and support in this research project. Your support and tweaking suggestions throughout the process drove me to remain focused on the direction, and angle presented. Your questions and probes in our discussions helped to broaden the analysis while at the same time assisted me in finalizing this project. For this, I am grateful.

Dr. Tariq Amin-Khan, your thorough feedback, and comments aided in presenting ideas I needed to clarify and expand, and for this, I remain thankful. Michael and Reheem Castello, the both of you remain my strongest critics and supporters, thank you both for being my sounding board and holding me accountable to writing daily.

To the participants who shared their experiences with me, I cannot mention you by names. However, I am forever grateful for your time and the contribution you've made to this project. It is mainly my interactions with state bureaucrats and farm workers that has led me to formulate this research. Listening to civil servants and SAWP farm-workers in St. Vincent and the Grenadines made me decide to analyze the temporariness of the program from a source country perspective. 
In memory of my grandfather, whose advocacy against exploitation, and empathy

for humanity has helped shaped my course of action and has given me the opportunities and privileged life I have today. 


\section{PREFACE}

I began this study on the premise that source countries, through their participation in circular migration have some role to play in the longevity of the Seasonal Agricultural Workers Program (SAWP). Most of these source countries are located in the Eastern Caribbean. Previous literature and studies have succinctly documented the roles of Canada and the Canadian farm employers regarding the treatment of the workers in the program. Interacting with farm-workers specifically from Caribbean source countries and previous research on SAWP provided insight that perhaps an inquiry needs to be conducted on source countries role in the program. With this background, I decided to investigate source countries' role in the program's longevity as a Temporary Foreign Worker Program (TFWP). I believe that balanced knowledge of the four major stakeholders in the program (receiving country, source country, farm employers and the workers) would enable a better understanding of the factor(s) that enables the program to continue without permanent resident pathways for the workers. This paper examines the source country St. Vincent and the Grenadines and its relation to the program.

Influenced by a transformative worldview perspective, I argue that research needs to intertwine with politics and a political change agenda in order to confront social oppression at whatever levels it occurs (Creswell 2014:10 citing Mertens 2012). I write this paper as a student supporter for SAWP workers, with the hope that it will stimulate further research that includes source countries and their functions in the program. Such investigations could propel policy changes for the SAWP. 


\section{LIST OF ABBREVIATIONS}

CAHRC - Canadian Agricultural Human Resource Council

F.A.R.M.S. - Foreign Agricultural Resource Management Services

IRCC- Immigration, Refugee and Citizenship Canada

LMIA - Labour Market Impact Assessment

MOU - Memorandum of Understanding

OECS- Organisation of Eastern Caribbean States

SAWP - Seasonal Agricultural Worker Program

TWF - Temporary Foreign Worker

TFWP - Temporary Foreign Worker Program 


\section{TABLE OF CONTENTS}

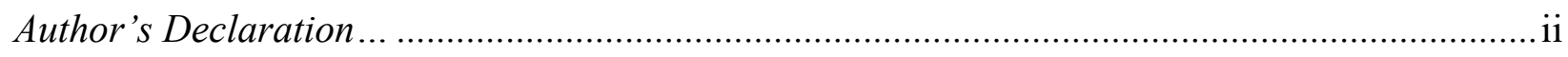

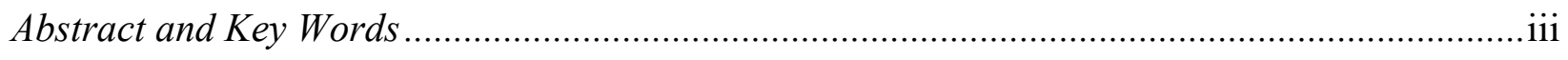

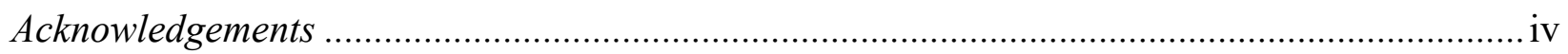

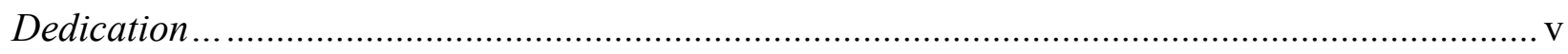

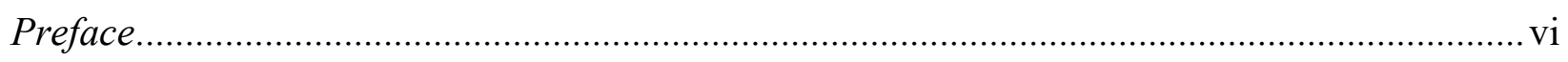

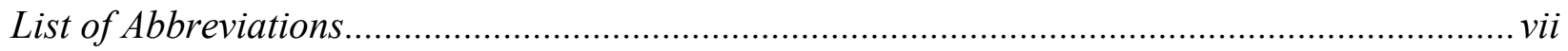

\section{Chapter 1: Introduction}

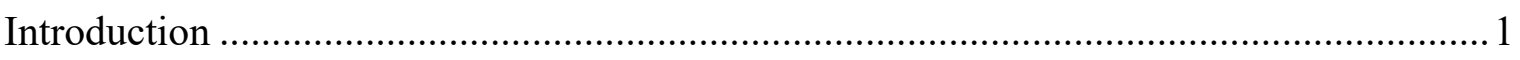

How does the SAWP works for source countries?...................................................... 4

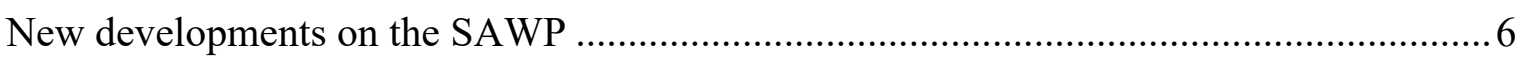

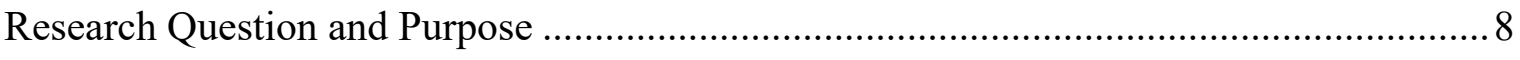

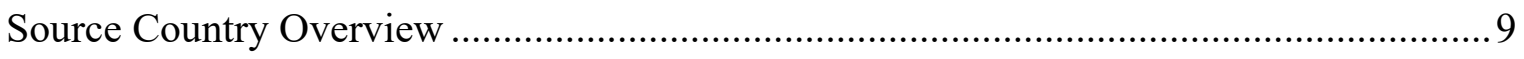

Outline of the Major Research Paper ................................................................... 9

\section{Chapter 2: Literature Review}

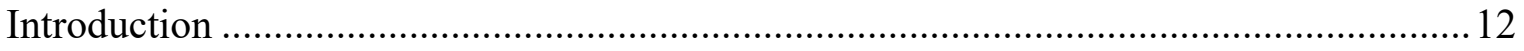

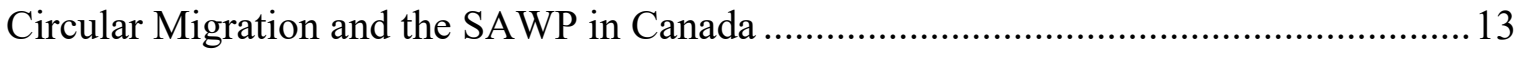

The SAWP comparisons with the Bracero Program ….............................................. 16

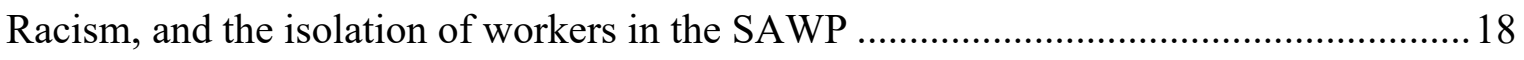

Advocates calling for change ... and the promotion of improved workers' conditions.....23

Factors currently contributing to the sustainability of the program in its present form .....26 


\section{Chapter 3: Methodology \& Design}

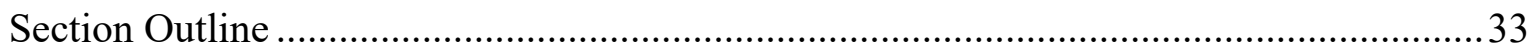

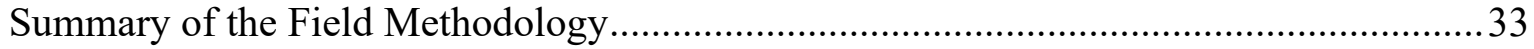

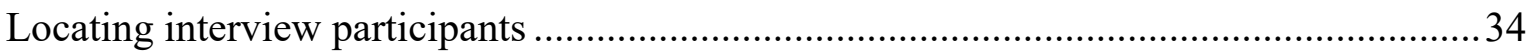

The interview process in St. Vincent and the Grenadines........................................ 34

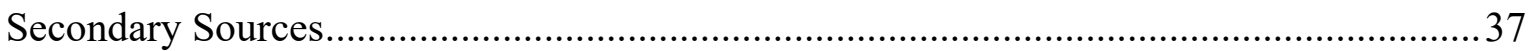

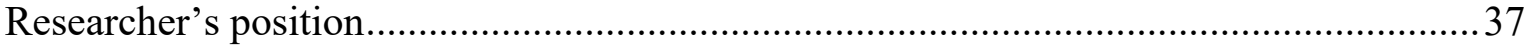

\section{Chapter 4: Research Findings}

Section Outline

Interview Findings:

SAWP farm worker vacancy allocations in OECS participating member states .............. 40

Discretion in the recruitment process for SAWP workers .......................................... 41

The MOU, and the creation and reproduction of dependency on the SAWP ...................44

The loss of control over remittances for the government and its effect on SAWP ...........46

The lack of interest by the Vincentian government in protecting SAWP workers' rights.. 48

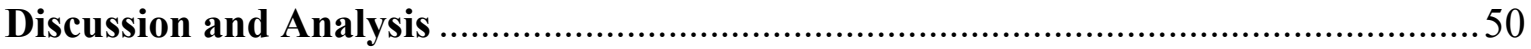

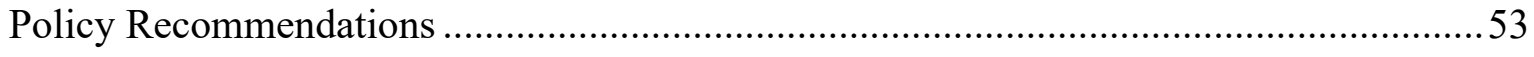

\section{Chapter 5: Conclusion}

Conclusion 
Appendix A: General principles for SAWP

Appendix B: Interview Questions: civil servants ...............................................................5

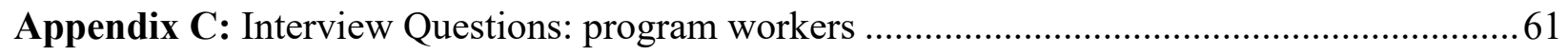

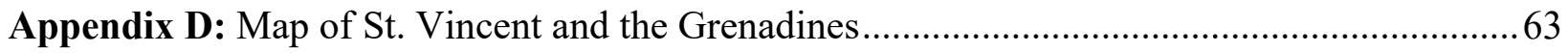

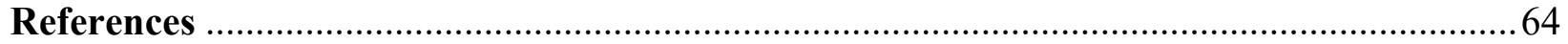




\section{CHAPTER 1: INTRODUCTION}

In recent decades, circular migration of migrant workers has become one of the most preferred patterns of labour migration for receiving countries (Castles \& Miller 2009). Constant \& Zimmermann (2010) refers to circular migration as the systemic and regular movement of migrants between their homelands and foreign countries typically seeking work. Circular migration is viewed as a best-practiced policy of 'managed' migration by international organizations such as the World Bank and International Labour Organization (Basok 2007). However, this particular view of circular migration is also critiqued by activist and researchers on labour migration and its management. In managing migration, the goal for receiving states is not only to supply labour for their economy but also to develop strategies to regulate who gains access to their borders and how they are monitored once inside those borders. To this end, high-income nations provide temporary resident work visa for individuals from foreign countries through various guest workers programs (Constant \& Zimmermann 2010).

Canada, traditionally a country of permanent immigration, has been rapidly expanding its Temporary Foreign Worker Programs (TFWP) in the last decades (Silverman \& Hari, 2016). This gradual shift from permanent to temporary migration is seen in Canada's push to formalize TFWPs. Legislation was formally introduced in $1973^{1}$, allowing large scale foreign workers into Canada, the focus was generally on individuals with post-secondary education or those individuals with practical skills recognised by regulatory bodies (Lemieux \& Nadeau 2015; Molnar 2018). However, since 2002, individuals who do not necessarily possess post-secondary education or regulatory skills are allowed under the TFWP (Lemieux \& Nadeau 2015; Elgersma 2014). The

\footnotetext{
${ }^{1}$ Though the caregiver program and the SAWP operated since the 1950s and 1960s respectively (see Brickner et al. 2010 \& Satzewich 1991)
} 
TFWP in Canada has four main streams: the agricultural stream ${ }^{2}$, the stream for lower-skilled occupations, the stream for higher-skilled occupations and, the Caregiver Program (Molnar 2018). The Seasonal Agricultural Worker Program (SAWP) and the Caregiver Program (CP) are two of the longest standing TFWP. While pathways to permanent residence remain problematic for all temporary foreign workers, it is especially true for the workers under the SAWP. The SAWP is unique in that workers can come only from particular countries for up to a maximum of eight months each year. TFWs in the other four streams can come to any country. The majority of approved TFW positions in 2018 - over 50,000 - were in agriculture and the majority of agricultural workers ${ }^{3}$ were processed under the SAWP (IRCC 2019). Moreover, SAWP is the only program without a pathway for permanent residence.

The program was initially formed through the bilateral agreement, signed between the Governments of Canada and Jamaica in 1966. The first batch of 264 Jamaican farm workers entered Canada on what was intended to be a temporary solution to the agricultural labour shortage (Smartt 1997). After Jamaica in 1966, the program extended to include Barbados and Trinidad (1967), Mexico (1974), and other Eastern Caribbean nations (1976). Currently, the program operates in the ten Canadian Provinces (F.A.R.M.S. 2018). Oversight of the program lies within the jurisdiction of Immigration, Refugee, and Citizenship Canada (IRCC) and the Department of Human Resources and Skills Development (HRSD). Administration of the program lies with the Foreign Agricultural Resource Management Services (F.A.R.M.S.) for English Canada. F.E.R.M.E provides the same duties in Quebec, Prince Edwards Island, and New Brunswick (F.A.R.M.S. 2019).

\footnotetext{
2 The SAWP standalone program now forms part of this stream

${ }^{3}$ Not all migrant agricultural workers come under SAWP; some of these temporary workers come under the agricultural stream inside the low-skilled pilot program (see IRCC website)
} 
The workers under SAWP are assigned to specific employers and given sector-specific working permits ${ }^{4}$ which mandates yearly work opportunities between six weeks and eight months. SAWP workers are contractually prohibited from being in Canada between the period of December 15 and January 1 inclusively, as outlined in the bilateral agreements (Hennebry \& Preibisch 2012; F.A.R.M.S., 2018; Lu \& Hou, 2017). Many workers under the program engage in this form of circular labour migration for several years, spending more than six months in Canada in each work cycle. The program is riffed with verifiable issues of worker mistreatment, employers abuse of power and the Canadian state inaction to reported instances of labour rights violation (Satzewich 1991; Dias - Abey 2017; Bauder 2008). Advocates for workers' rights and some academic researchers hold the Canadian state responsible for the program's prolonged temporary status that contributes to the mistreatment of workers, inter alia (see Smartt 1991; Satzewich 1991; Silverman \& Hari 2016; Perry 2012; Ruhs, 2016; Basok 2000). When the Canadian Government in 2014 introduced extensive immigration changes to its temporary foreign workers programs, SAWP was one of two foreign worker programs exempted from those changes. One of the arguments put forward for that decision was the continued labour shortage in the Canadian farming community (Lu \& Hou 2017). Researchers and theorists on TFWP specifically on the SAWP blame the Canadian Government, and rightly so for the continuous temporary resident status of the workers. Further, accusations focused on the administrative body of the program, the (mis)treatment of the workers by farm employers and the high rate of unemployment and poverty experienced in source countries. However, there is a gap in the literature on source countries culpability. The role of

\footnotetext{
${ }^{4}$ At the time this MRP was completed SAWP workers no longer have employer specific work permit, but can move between farms with the worker's consent and a transfer request, though the paperwork and process are complex
} 
source countries could very well be a factor in the program's longevity as a 'temporary' source of employment without a defined pathway for permanent residence for the workers.

\section{How does the SAWP works for source countries?}

Jamaica, Barbados, Trinidad and Tobago, as well as Mexico, have individual liaison representatives from their governments who facilitate the contractual agreements between the workers and the farm employers. The island states of Anguilla, Antigua and Barbuda, Dominica, Grenada, Montserrat, St Kitts- Nevis, St Lucia and St Vincent and the Grenadines are represented by the Organization of Eastern Caribbean States (OECS) - an overarching body that represents the nations in the Eastern Caribbean who participate in the program. The OECS is unique in that SAWP agreement with the OECS serves seven of the ten members states. Excluded from SAWP in the Eastern Caribbean are the three associate member states: Petit Martinique, Guadeloupe, and the British Virgin Islands. While this study did not delve into the economic and development detail of the OECS Treaty of Basseterre ${ }^{5}$, it is important to understand that bilateral agreements with member states and foreign nations usually affects the international agreements and other external economic relations (revised Treaty of Basseterre [Article]4.2(g) (OECS 2016). SAWP is an international agreement between Canada and the Eastern Caribbean countries all of whom are represented by the OECS. This means that individual member states of the OECS under SAWP do not approach the receiving country administration (F.A.R.M.S.) or the employers, rather representation for the seven OECS member states are conducted by a delegated chief liaison officer $^{6}$ and an assistant liaison officer ${ }^{7}$.

\footnotetext{
51981

${ }^{6}$ Olaf Fontenelle, St. Lucian citizen

${ }^{7}$ Charmaine Blackman, Vincentian citizen
} 
The case of source countries participation in the SAWP is vital for research as it helps to fully conceptualize the program's longevity and fully illustrate the degree of coercion implemented into curtailing labour market freedoms for the program's participants. Beckford (2016) acknowledged that Caribbean source countries have not been significantly critiqued in research on the SAWP. Smith (2015) posits that a resurgence in theories of capitalist-imperialist activities, including the position of Canada in global affairs, fail to critique the place of labor migration in its discourse. Using the SAWP as an illustration, Smith (2015) contextualized the Canadian-Caribbean relations as a racist-imperialism nexus, arguing that the Canadian state is an imperialist one that used agricultural labour migration from the Caribbean to secure an empire abroad. Canada's transnational regulations in the SAWP are rooted in global inequalities and socio-historical relationships between the Caribbean and Canada.

While these socio-historical relationships are longstanding sites of production of both the politico-legal authority and 'unfree' labor, they have been, and remain unequal. Unfree, in this case, is the lack of choice and alternatives for workers. The high unemployment rates in source countries contribute to the dismal choice and employment alternatives for SAWP workers. Hence, the issue is not whether the workers are 'free' to participate in the program or 'choose' to participate in the program but rather the alternatives the workers are faced with.

Canada's seemingly welcomed presence with developing countries stemmed from the notion that Canada has no imperialist past. This misguided view was echoed by Canadian Prime Minister Stephen Harper pronouncing the virtues and assists of Canada disassociating it from its colonial history (O'Keefe 2009; Kelley \& Trebilcock 2010; Smith 2015). However, a minority perspective argues that restriction in the program's coerced administration could not have been successful without the cooperation of source countries (Wright 2018; Kestler-D'Amours 2016). 
Tied to this cooperation is (1) the remittance benefits managed migration provides for these countries and (2) the competitiveness of source countries to retain and attract employers for their citizens (Melancon \& Grenier 2015).

\section{New developments on the SAWP}

More recently, some tangible steps have been made to address the concerns of the workers ${ }^{8}$. In 2014 the Federal Government of Canada removed the employer restricted provision of SAWP work-permit; however, the permits still remain program-specific (IRCC 2019). This means that the workers can transfer to other SAWP employers if they agreed to be transferred without the processing of a new LMIA. Transfers can sometimes happen when work on one farm has ended and another farm has work still in progress. Rarely, would a worker be transferred if there is a disagreement between the worker and an employer, in these cases the worker is usually sent home (civil servants and workers interviews). Additionally, the Province of Saskatchewan through its Provincial Nominee Program ${ }^{9}$ in 2018 implemented a pathway to permanent residence for workers, which include worker under SAWP (Government of Saskatchewan 2018). However, the pathway is employer-driven, requiring the employer to sponsor the employee, and outlining a fulltime job offer with no foreseeable termination period. However, even with this avenue for Permanent Residence under Saskatchewan's Provincial Nominee Program, the prospect remains slim since the specification for Permanent Residence outlines that the job must be permanent. (Government of Saskatchewan 2018). If the employer does not offer the worker a full-time job and submits an employer support form for the program, the SAWP worker would not be able to transition to permanent residence. Thus, both the removal of employer specific work permit and

\footnotetext{
${ }^{8}$ The latest of these changes is the right to apply for an open work permit for TFW with verifiable cases of employer abuse. (Go, Douglas \& Konanur 2019).

${ }^{9}$ Provincial Nominee Program offers a route to permanent residence where provinces nominate individuals who wish to immigrate to Canada and settle in their province. See IRCC website
} 
the Saskatchewan's Provincial Nominee Program permanent residence pathway, benefit the employer since the former was implemented after farmers experienced long delays in getting a new Labour Market Impact Assessment ${ }^{10}$ in order to hire a SAWP worker already in Canada and who may have finished on one farm before December 15. The latter requires the employer's input perpetually placing the worker in a vulnerable position in order to get the assistance of the employer.

Canada-based research with SAWP conclude that unique circumstances resulting from the TFW's temporary migration and employment status presents particular challenges for transitioning to permanent residence, especially since many of the positions are regarded as seasonal and therefore does not offer permanent employment (Satzewich 1991; Hennebry \& Preibisch 2012; Silverman \& Hari, 2016). Since the majority of research on the SAWP is conducted within Canada there is a wealth of information of the program on the noticeable and concealed roles of the farm employers and the receiving country. Moreover, even though there has been a significant amount of research done on the Canadian state policies, as well as the status, conditions, and experiences of workers on SAWP in Canada, there has hardly been any research on the role of the source countries in the program.

Given the formally bilateral character of the agreements that have created and sustained SAWP, the absence of research on source countries is a big gap in knowledge about SAWP. Moreover, limited attention has been paid to the roles of source countries in maintaining the program, and even less is known about whether source countries benefit from the continuous temporary working and residence status of the workers in the program. This research not only provides a better understanding of the temporary nature of the labour migration in SAWP from the

\footnotetext{
${ }^{10}$ LMIA is a document an employer may need to get before hiring TFW. It is to ensure that the employer has advertised the job for a specified time and no Canadian citizen nor Permanent filled the position. See IRCC website
} 
perspective of a source country, it also provides additional information regarding the challenges of the workers in the program to transition to Permanent Residence in Canada.

\section{$\underline{\text { Research Question and Purpose }}$}

The purpose of this major research paper (MRP) is to explore whether source countries have any weight or responsibility in maintaining the temporary nature of residence and employment for migrant farm workers under the Seasonal Agriculture Worker Program. I looked at the power imbalance between the workers and the State in the source country through a qualitative method approach by examining the bilateral receiving and source country agreement and its application to the recruitment process and subsequent working experience of migrant farm workers.

My research questions are:

a) What role(s) do government policies of source countries play in maintaining the temporary status of workers under SAWP in Canada?

b) What are the policies of the source country that support or do not support workers?

c) Are these policies written or inferred through practice?

Accordingly, the answers to these questions were used to establish whether source country government have any weight or say in determining if the workers on the program can transition to permanent residence and if so, what are these? Further, the questions aimed to address the gap in the literature that neglect discussions of source countries in the SAWP. In so doing, the findings could enhance the literature on SAWP with the new addition of research on source countries - a major stakeholder in the program. Since this was a critical exploratory study on source countries role in the program, the questions were deliberately broadly designed. 


\section{Source country examined}

I chose St. Vincent and the Grenadines as the source country to conduct my research because of my familial connections. Many of my extended family and friends live in St. Vincent and the Grenadines and I regularly visit the island. Through these connections and experiences, I have interacted with many individuals who participate in the SAWP and individuals with knowledge of the program. These established relations made obtaining the data to explore my research questions possible. Additionally, St. Vincent and the Grenadines is a suitable source country to study because of its rates of unemployment within the state. Given its membership within the Organization of Eastern Caribbean States (OECS), Vincentian nationals - as well as other member states - are able to seek employment in other OECS member state and vice - versa. Moreover, given the timeline (three months) to complete this MRP, these connections aided in meeting this deadline since familiarizing oneself with the research setting was already established.

\section{Outline of the Major Research Paper}

The following chapter provides a literature review, looking into the role of source countries in the shaping of the SAWP. Since the SAWP is categorized as a circular migration program, I provide a brief discussion of the impact of circular migration on the SAWP. Subsequently, I present my own empirical research in St. Vincent and the Grenadines as a case study examining and problematizing the various roles played by source countries arguing that while many scholars and advocates rightly argue that Canada is 'ultimately' responsible for providing a transitionary pathway to permanent residence for the SAWP, source countries have some degree of culpability in the situation.

My argument is that source countries carry-out the role of policing and managing the SAWP - thus becoming complicit and compliant to demands of the Canadian state and its farmers. 
The 'development' of both source and receiving countries comes at the expense of the workers involved in the program, and while Canada has a higher degree of control in determining who becomes permanent and who remains temporary, source countries have some role in this arrangement. Even though the receiving country defining the status and conditions of migrant workers, exercise much of the power over them, power relationship also exists between source countries and SAWP workers. For example, Vosko (2018) outlined the blacklisting of Mexican workers from the program by the Mexican Government - an action viewed as a prohibitive strategy for workers joining trade unions. In this instance, Mexico successfully argued that while their blacklisting of workers joining trade unions in Canada breached aspects of British Columbia Provincial Laws, Mexico was immune to the provisions under the regulations (Vosko 2018). They argued that the court decision of the trade union board has no value under Canada's federal State Immunity Act (1985) and as such the trade union ${ }^{11}$ has no jurisdiction over the Mexican Government unilateral decision to blacklist its' citizens from SAWP (Vosko 2016, 2018). Apart from Vosko's studies on Mexico, there is little data on the roles of source countries, particularly Caribbean source countries in maintaining the temporary nature of the SAWP workers.

My chapters are organized as follows: chapter one provides background information by introducing circular migration and TFWP, specifically the SAWP. It illustrates the mechanism used by states to manage migration and also outline the questions this research sets out to answer. It also provides an overview of the source country discussed and the outline used for this research. The second chapter comprises the literature review of the program and examines some of the factors currently contributing to the sustainability of the program in its present form. It also provides a brief review of the impact of circular migration on the SAWP. Chapter three outlines

\footnotetext{
${ }^{11}$ To date SAWP workers are restricted from bargaining collectively in Ontario, a decision upheld by the Supreme Court of Canada see Ontario (Attorney General) v. Fraser, 2011 SCC 20
} 
the methodology and design of the study outlining the details of the field methodology and secondary material. It ends with the researcher's position in the study, paying attention to biases and measures taken to address them. Chapter four outlines the findings gathered from the data in the interviews and a discussion of those findings, ending with policy recommendations from the data collected. The final chapter (5) recaps the findings, examines the implications of those findings and present the conclusion drawn from these implications. 


\section{CHAPTER 2: LITERATURE REVIEW \\ $\underline{\text { Introduction }}$}

There are many 'benefits' to the SAWP for the main stakeholders involved in the program. For instance, Canada acquires reliable workers for its farmers and source countries acquire employment for its citizens. Additionally, the farmers have an abundance of choices for reliable workers through the source countries in the program. The workers in the program can have some form of employment that enables them to provide for their respective families in their countries of origin (Andre 1990; Basok 2007; Hennebry \& Preibisch 2012; Smith 2015). However, while the workers participating in the SAWP program are integral to the program through the sowing and harvesting of farm produce, the 'benefits' they receive in the program is controversial. Weighing the social implications of workers absence from the source country, the 'benefit' to workers remains a basis of contention in the extensive literature on the program. From the standpoint of some researchers' governments are responsible for creating employment opportunities for their citizens (Andre 1990; Smith 2015). Hence, to say that the workers' 'benefits' from the program is superficial, given the responsibility of the governments.

Advocates in Canada continue to petition for the rights of TFWs, including the SAWP workers. These appeals include the immediate right to permanent residence under the program or a transitionary pathway towards permanent residence (Perry 2012; Elgersma 2014; Nakache \& Dixon- Perera 2015). Given its almost 53 years in existence as a source of labour for Canadian farmers there is an extensive amount of research on the SAWP examining the (mis) treatment of workers by Canadian farm employers and the Canadian state with little or no research on the roles source country play in the program's longevity as a 'temporary' avenue of labour. Hence, to account 
for the complexity of some of the more prominent issues, this literature review is broken down into four broad headings.

The first heading 'Circular migration and the Seasonal Agricultural Worker Program in Canada' examine some of the arguments made for the 'best-practiced' model allusion to the program. It discusses under this heading some of the interest of capitalist accumulation in the agricultural sector drawing on links to the political economy. "Bracero, racism arguments, and the isolation of workers in the SAWP" examines the more pronounced differences between the SAWP and the Bracero program. It also examined arguments of the program as imbedded in racism and whether it still functions as a racists program in its exploitation of the workers' labour. The third section, "Advocates calling for change, legal consciousness, the sovereignty of states, and the promotion of improved workers' conditions," examines some of the changes called for by advocates and researchers and the direct role of one source country restricting their citizens from joining trade unions in Canada - a move widely seen as restricting the workers from seeking ways to improve their working conditions in Canada. Section four examines "some of the factors currently contributing to the program sustained in its present form as a TFWP." The final section examines "the impact of circular migration and how it is used to manage the SAWP."

\section{Circular Migration and the Seasonal Agricultural Worker Program in Canada}

A World Bank study (2006) mentioned circular migration programs such as the SAWP as important development mechanisms that play an integral role in poverty reduction. This particular study examined the argument in favour of greater labour mobility for individuals (in this case Pacific Islanders) who were unable to source jobs domestically. The report submits that the excess labour supply in countries of the global South and the excess demand for labour in high-incomed global North countries is a "potentially mutual beneficial movement of labour" (World Bank 2006: 
iii). Though much of the income earned by participants in the SAWP is presumably spent in Canada, St. Lucia, one of the Caribbean countries participating in the program praised the economic contribution of the program indicating that with just 231 workers sent to Canadian farms, a combined gross income of CAD\$4,276,517 or EC\$ 8,553,034 was realized (VP Digital, 2016). Employers and states involved in circular migration programs also view circular migration programs as 'best practiced models.'

However, Hennebry and Preibisch (2012) examined this 'best-practiced model' of circular migration touted by the World Bank through the perspective of states and employers and suggested otherwise. They argued that in the age of managed migration Canada's method of this 'best practiced model' constitutes a backward step from international standards. The perception of its idealized model is nothing more than an idealized myth evident in the increasingly restrictive policy creation of the fairly recent programs compared to the older programs. Hennebry and Preibisch (2012) identified three benefits of the program from the perspectives of the employers and the states: "first it operates through a demand-driven mechanism; secondly it provides support to the agricultural industry at a low cost to the Canadian state, given the bilateral agreements with source countries. Most importantly, the unfree labour relations have enabled reliability, consistency and confidence of the employer of an adequate labour source.

This theorization finds support by Ruhs (2016) in calling for the International Labour Organization's public engagement in responding to openness on one hand and rights in labour immigration policies on the other hand. Situating the argument from internationally recognized rights-based approaches to migration the author contend that international organization best practices should be implemented. However, as O'Brien (2014) noted, enforceability of these international organizations [best practices) for global labour protection is limited. 
Critiquing the lack of in-depth research on the role of the state in the program's management, Asomah (2014) posits that the state plays a significant role in the policy implications of the SAWP through its interest of capitalist accumulation in the agricultural sector. This he maintained is done through neoliberal globalization and segmentation of labour theory in regulating the labour-capital. For the North, Canada "has structured the relations of labour and capital in a manner that reflects the interest of capital at the expense of the vulnerable migrant workers" while the South has some role in capitalist accumulation when signing "apparently nonstrategic international free trade arrangements" opening its borders to multinational corporations and the importation of foreign produce. Free trade agreements also contribute to the displacement of the masses and small business through land grabbing, increased trade competition and, increased poverty in the global south.

Supporting this line of argument Satzewich (2007) offers a critique of the political economy theory of immigration by examining the reason(s) Mexico was added to the SAWP. According to Satzewich, neoliberalism (the tendency to favour free-market capitalism) where Canada immigration policy changed to attract more highly skilled immigrants offers a partial explanation to Mexico's inclusion to the program. Satzewich highlighted two points of view of immigration officials and bureaucrats: 1) a win-win strategy, in which the government was able to favourably respond to the employers' interests and at the same time resolve its legitimacy crisis faced in the early 1970s, when employers sought the services of marginalized and undocumented migrants instead of the overpriced SAWP and 2) the incorporation of Mexican workers help in resolving the challenges it faced with its electoral claims to supply Ontario farmers with suitable amounts of farm labour. 
A link was drawn between business interests and Canada's immigration policy. Economically the federal government interest in having greater leverage over the Caribbean governments bargaining ability was acknowledged. With the incorporation of Mexico into the program, the size of the workforce expanded massively with more than $50 \%$ of the workforce being Mexicans. This strategically weakened the bargaining power of Caribbean Governments as the competition stake rose and also provided the employers with an even larger pool of workers. Significantly important was that the wage increase and improved working conditions pressures of other migrant farm workers in Canada were mitigated with additional competition from Mexico's inclusion.

A distinctive contention of the author in his critique of political economy theories is that political economic theory both historical and current focus on the Canadian state and employers as the most significant beneficiaries of neo-liberal immigration policies. Scant attention is paid to the interests and actions of immigration bureaucracy, dismissed as "simply a tool in the hands of the economically powerful" lacking independent agendas and contradictions (Satzewich 2007). Satzewich concluded that Mexican workers inclusion to the SAWP benefitted farm employers, without the push factor of lobbying by interest groups. However, the benefit was of greater significance to Canadian immigration officials as it allowed them to repair a legitimacy crisis in the form of managed migration and withstood deteriorating working conditions of Canadian workers. Hence, to determined circular migration as a 'best practiced model' is problematic since this practice of managed migration is at the expense of the workers participating in the program.

\section{The SAWP comparisons with the Bracero Program}

The concept of managed migration was discussed by Basok (2000) who investigated the American counterpart of the SAWP, the Bracero Program. The Bracero program was another bilateral 'guest 
worker' or 'temporary labour' program that formally operated in the US between $1942-1964 .^{12}$ Like the SAWP, this program operated through an agreement between the receiving and source country (in this case Mexico) governments. While the Bracero program and the SAWP are similar in terms of workers' rights, living and working conditions, their administration differed. First, the size of the Bracero program was vastly different in terms of numbers - significant in program management - than the SAWP (Basok 2000). At its peak (1957) Bracero saw in excess of 400,000 workers from Mexico, whereas Canada has admitted around 5,000 workers form Mexico (under SAWP) per year (Basok 2000). 35,000 of SAWP workers from all 12 source countries filled labour gaps in the agricultural sector. There is an estimated 46,500 labour position for SAWP workers expected by 2025 (CAHRC 2017). Hence, even though the Bracero program existed for 22 years the number of Mexican foreign workers admitted under the program outweighed the number of workers under the SAWP making management from a sheer number argument less feasible.

Although, the Bracero Program was also founded on bilateral agreements between Mexico and the US, its recruitment process differed from the SAWP. Under the Bracero Program, workers could be recruited from within Mexico or within the US (Johnson-Gonsalves 2016). The US also used the program as a coercion tactic to force trade negotiation strategies with Mexico. Mexico (prior to and during the 1940s) tried to stop its citizens from crossing into the US and instead assist in developing Mexico with their labour. However, at the same time the US wanted to develop its own economy. Thus, the US Government, also processed potential workers at the Mexican/US borders under the Bracero program. Additionally, during tense negotiation periods, Mexican citizens caught undocumented in the US were also processed under the program (Johnson-

\footnotetext{
${ }^{12}$ See Bill Johnson González (2016), “Anthony Mann’s Border Incident, the Bracero Program, and the Government Procedural."
} 
Gonsalves 2016). This action by the US Government circumvented Mexico's efforts of managing migration by converting undocumented Mexican workers caught in the US to the Bracero program. Recruitment under SAWP on the other hand, is done solely by the source countries and work visas under the program can only be acquired through participating source country governments. There is no conversion to the SAWP of workers outside of the source countries. Hence, while the programs are similar in their treatment of farm workers, the way in which they were 'managed' contribute to SAWP's continued operation and the end of the Bracero program.

\section{Racism, and the isolation of workers in the SAWP}

Vic Satzewich (1991) a leading researcher on migrant labour in Canada is widely used as a starting point of research on the SAWP. "Racism and the Incorporation of Foreign Labour: Farm Labour Migration to Canada" is often referenced for answers to the reasons for the implementation of SAWP in Canada. In his work Satzewich (1991) provided an historical backdrop to the introduction of Caribbean migrant labour in the Canadian labour market. He began by illustrating that prior to the establishment of the SAWP, German prisoners of war, Japanese-Canadian internees and conscientious objectors were used for the labour shortage during WWII. However, they proved unreliable for agricultural labour since they leave the farms and unharvested crops rotting after a short period of time. The decision to use the above groups of workers was taken to curb the flow of undocumented migration that was causing an issue for the government at the time. With these workers abandoning the farm, farmers once again began hiring undocumented migrants to carry on their business. At the same time, they continue to pressure the government for assistance in finding permanent labour for the agricultural sector, since other forms of temporary labour including school-aged children on school breaks, military personnel rejected on medical

grounds and women from urban areas (Satzewich 1991). Hence, after WWII Canada began a 
scheme with Polish military veterans and other refugees from Europe's poorer countries to fill the agricultural work sector with the agreement that they would work one or two years on farms in Canada as a prerequisite for Canadian citizenship (Satzewich 1991). This framework also proved ineffective since, both groups left the farms after the waiting period, for urban areas with better pay and working conditions (Satzewich, 1991). Caribbean Governments, on the other hand, were looking to solve their own employment shortage, with Jamaica and Barbados lobbying the Canadian state since 1947 "to allow farmers in Canada to make use of migrant workers from their countries" (Smart1997 citing Satzewich 1988:288). Given the positive feedback of Florida's cane growers experience with Caribbean labour, the Canadian state facing continued labour shortage signed an agreement with Jamaica in 1966, thus beginning the program with 264 men (Smart, 1997).

Despite viable arguments of the imbedded restrictiveness used to sustain labour in the agrisector, the historical account of Canada's racist immigration policies is still seen as a guiding principle for maintaining the temporariness of the program. Scholars (Perry 2012; Basok 2000; Bauder 2008) have all used Satzewich's (1991) work as a guiding framework for the historically racist recount of the Canadian Immigration System and its less enthusiastic admission of nonwhite individuals to support the argument for the racist embedment in the program. Satzewich (1991) documented the justification used by the government ${ }^{13}$ to implement immigration policies that prevented permanent settlement of individuals - in this case Caribbean nationals - Canada did not desire. Within this frame was the perception of blacks as lazy and later, incapable of coping with the changing climate. This racist perception and framing scholars argued was the reason for

\footnotetext{
${ }^{13}$ Until 1966, the Canadian Government determined immigration settlement through race base determinations, in addition memorandums obtained from immigration achieves outlined the racialized rationale used by the department of immigration in circumventing and restricting black immigrants and migrants (see Satzewich 1991)
} 
preliminary refusal to seek Caribbean nationals for the program (Satzewich 1991; Perry 2012; Basok 2000; Bauder 2008).

Given the depiction by Satzewich of Canada's racist immigration policies, Perry (2012) argued that the SAWP is a legalized colonially racist program that continues to find its legitimacy in multiculturalism. 'Multiculturalism' is a law of Canada supporting distinct cultural, ethnic or racial groups in Canada. Perry's contention is that due to the legality of 'multiculturalism' Canada is able to covertly continue its racial treatment of Caribbean individual in plain sight. He contended that the program's racism is imbedded in the idea that the work performed in the program is such that no Canadian citizen or permanent resident would undertake. Canada continue to fulfill labour shortage with visible minorities under the umbrella of an immigration policy that accepts individuals whether temporary or permanent regardless of race. Thus, Canada is able to maintain its image as a multicultural, pluralistic society in continuing the program while at the same time keeping the workers on the margins with limited rights. The point was made that race continues to play a covert role in the program's admission and execution. Supporting this argument is Satzewich's (2007) latter research questioning the Portuguese workers exclusion from the program around the same time Jamaica was accepted. If the SAWP's policy was solely racist, then the Portuguese workers would have been better favored than the Caribbean nationals. Rather it was the visible Portuguese presence in Leamington that raised concerns for including them in the program.

Basok (2000), alluded to the visible Portuguese community presence in Leamington as a concern for non-return after the end of a contract, which could have increased the legitimacy crisis on migration that the government was facing and also explained why the Portuguese were excluded from the program. At that time the Canadian Government was under 
pressure for its documented racist policy of preventing marginalized individuals from settlement while at the same time managing irregular labour activities. The temporariness of the program removed the explanation of the government to the electorate of taking in more individuals into Canada and the inability of finding work. Additionally, management by the source and receiving countries is highly visible in these migrant labour schemes with bilateral agreements. Thus, including the Jamaicans, rather than the Portuguese, made 'managing' the program easier given the visibility of Portuguese in Leamington (Basok 2000).

Likewise, Bauder (2008) in examining the role media plays in the framing representations of the SAWP, finds that media discourse helps shape the public's consent that assists in the legitimization of labour exploitation. First, is the portrayal of these workers as valuable economic resources; second the depiction of these workers as skilled agricultural labour and thirdly as a social problem and potential criminals. Employing them, therefore, is an act of compassion that provides the assurance of assistance for poor families in the global South. Bauder (2008) identifies the program as the new serfdom, where the analogy of bonded labour is connected and increases the reliability of the labour making the incentives to improve the conditions for the workers nonexistent. Moreover, this bonded labour is identified as the new racism whereby the efforts to further subjugate the workers' free will is done along racial lines; through the dichotomy of us versus them represented by the 'foreign' status of these workers. The benevolence of Canada is presented in the form of foreign aid for these global South citizens. Canada's populist history helps maintain this discourse of normalization for the program by pitting white nativism above all else and commodifying the workers in the program as insurance policies and safety valves (Bauder 2008). While overt racism as outlined by Satzewich (1991) seems non-existence, the linkage of racism to the program still remains, represented in the economic necessity narrative. 
Further, within the program policy, the government would have created an option for its legitimacy without the overwhelming oversight and cost responsibilities since the cost of the program was borne predominantly by the farmers, the workers and to a lesser extent the source countries governments through their liaisons. Additionally, the Caribbean saw an avenue for economic development opportunity since they were facing their own inability of finding employment for all of its citizens. The Portuguese exclusion from the program as such could have very well being economic.

Another argument supporting racism as a founding reason for the implementation of the SAWP agreement was discovered in the discourse of the caregiver program. Originating in the Caribbean during the mid-1950s, the program then known as the Caribbean Domestic Scheme was implemented to circumvent the labour shortage in the domestic arena. These Caribbean nationals were given the option to work with the presumption of immigrant work status, similar to the Polish workers, in that they were allowed to settle permanently after being employed as a domestic worker for at least one year (Brickner \& Straehle 2010)

The program required women to be single and childless. However, it soon became evident that these women had families as the influx of family sponsorship flooded the Department of Immigration since the women applied for family reunification once their conditional period was lifted, and they were permanent residents (Brickner \& Straehle 2010). The result of their action was the implementation of the temporary employment authorization in the 1970s similar to the SAWP program in that it allowed the worker to renew the work authorizations yearly but removed the access to permanent residence. However, amidst outcry of the deteriorated working conditions access was again granted in 1981 allowing the participants of the program to transition to permanent residence after a period of work (Brickner \& Straehle 2010). The caregiver program 
history supports the justification of embedded racism within the SAWP in three ways: first, SAWP compared to the caregiver program offers migrant labour work rather than immigrant labour work categorization. Immigrant labour has the potential or presumption that after a period of temporary work, settlement would be established if desired. Migrant labour on the other hand, offers seasonal work with the presumption in most cases, that after the period of employment, the workers would leave Canada. The presumption of settlement is neither encouraged and seldomly exist, in so far as migrant labour is practiced. Hence, there was no need to offer permanent settlement after any length of time. Secondly, in so doing it effectively barred the reunification of the workers and family members and thirdly, outlining the program as seasonal effectively curtailed the permanent settlement of those considered the 'least desired individuals' in Canada (Satzewich 2007).

\section{Advocates calling for change, legal consciousness, the sovereignty of states and the}

\section{promotion of improved workers' conditions.}

Calling for a litany of changes to the temporary foreign worker program the Canadian Labour Congress (2016) outlined 13 recommendations, one being implementing a pathway for permanent residence for the SAWP. It addressed the accusations of the employers and the competitiveness of the workforce for Canadian citizens and permanent residents, noting that while other migrant workers in the agricultural stream can access Employment Insurance (EI) benefits, the EI regulations s55.01 (3) effectively disqualify SAWP participants from claiming the benefit further sustaining their unequal status even comparable to other workers in their precarious position.

Hence, within the framework of legal consciousness, Dias-Abey (2017) considers the ability of intermediate stakeholders to affect change for migrant workers. Legal consciousness as a theory emerged with the realization that knowledge of the law, while necessary for action does not automatically translate into action (Dias-Abey 2017). Therefore, an explanation of how people 
experience and understand the law became necessary. However, since labour organizations must be cognizant to the political economy as a determinant for course of action, it is imperative to have a combination of workers and allies, to create instrumental alliances to overcome the unfreedom of the workers' participation. Vosko (2018) acknowledged that while this is true, managed migration has the ability to institutionalize deportability even in cases where the workers are able to unionize. One illustration is the requirement of the employers' favourability evaluation of workers during the previous period - a requirement for subsequent selection to the program. This practice embedded in policy strategically prevents the autonomous participation in collective bargaining. Hence what this sub-policy does is undermine collective bargaining membership by encouraging workers to tolerate unfair labour practices in order to secure positive evaluation and future participation in the program.

An analysis noted is the trans-global legality and sovereignty of states in bilateral agreements of the SAWP. In the instance of unionization, the Mexican Government was seen as the circumventor of its nationals bid (Vosko 2018). A possible explanation for such actions by a source state was the competitive nature of the program through the ability to choose employees from a specific set of countries and not just one country (Satzewich 2007). Hence, unionization could have impeded Mexico's selection - an action unwelcomed by the state. Resolution of the varying discrimination in the program cannot be solved with band-aid solutions such as trade union membership, since, rights infringements are still allowable within these circumstances. The Mexican case shows that the problem lies with the design of the program itself, which allows the institutionalization of discrimination.

Moreover, the structure of the program itself is overtly power-imbalanced with the employer holding most if not all the power and the worker little to no power. This imbalance 
enables the discrimination of the worker and places the success or failure of the program on the relationship between the employer and worker. Adopting a qualitative approach, Beckford (2016) examined the experiences of the program from the Caribbean workers perspective. His research supported observations of paternalistic tendencies among employer and employee. It also confirmed to some degree the alienation and exclusion felt among workers in the community. One significant finding of the study was the inaccuracy of the perception that all the participants of the program were low skilled and illiterate. It found that the two key informants had over 20 years' experience and were on special multi-year contract, which spoke to their skills and experience. It also illustrated how certain skills are devalued by the Canadian State. Further, among the younger participants, eighty-nine percent completed secondary education, equivalent to a high school diploma in Canada.

Contributory exaggerated estimates about the number of temporary migrant workers in Canada, coupled with the rising rate of unemployment has led to the decline in public- 'popular support' (Silverman \& Hari, 2016). The dual federal/provincial involvement in the program effectively contributes to the limitation of potential structural reform of the program. Federally, approval is required for the participants while compliance and monitoring of workers treatment reside with the provinces through F.A.R.M.S. (Silverman \& Hari, 2016). Hence, despite the tangible need for workers in this category, a pathway or transition to permanent residence in Canada is not a part of the program agreement and a partial reason for this is the distinction between migrant workers and immigrant workers.

Migrant workers are categorized both concealed and noticeably as 'guest workers' filling a temporary shortage with the caveat that they return to their country of origin after the seasonal work has ended. Immigrant workers, on the other hand, are categorized as potentially permanent 
workers leaving their country of origin to fill the permanent labour shortage in the country of destination. This categorization and linguistic classification are problematic for the workers employed under the SAWP, since in most cases these workers are employed yearly in the same field and at times with the same employer. Despite this reality the avenue to reside as an immigrant worker is not extended to the individuals participating in the program. Hence, the living and working conditions of the SAWP participants demonstrate the collective systemic and policy exploitation of one of the main stakeholders in the program. Advocating for improved conditions around this issue would be to remove some of the condition of restrictive circulation of the participants to address the power imbalance.

\section{What are some of the factors currentlv contributing to the sustainability of the program in its present form?}

Global organizations mandated to monitor and provide equitable means of labour hail programs such as the SAWP as 'best practice models' for both developed and developing countries. This best practice model is embedded in the concept of managed migration discussed by Basok (2007). Managed in the sense, that circular migration is now looked at by high- income countries as a feature to be regulated at state, migrant, and immigration policy levels. The goal is not only to supply labour for their economy but also to regulate who gains access to their borders. It tends to foster both bi-polar and multi-polar migration characteristics resulting in the need for organized dialogue between source and receiving countries (Constant \& Zimmermann 2010).

Apart from the farmers lobbying for a satisfactory labour force, one that would be adequate and reliable in assisting with the harvesting and cultivation season, the Canadian Government's interest to regulate border entry and maintain an adequate labour force were met with SAWP

agreement and implementation.Another factor that contribute to the program's continued 
sustainability is the significantly different marital status profile of participants where married or common-law status' were higher for men than women (Beckford 2016). This is an interesting dynamic given the rise of feminist movements and public policy for women groups. It was explored by Silverman and Hari (2016) through a feminist-migration studies analysis. In their analysis the authors found that the immigration policy of Canada is overly favorably to temporary or probationary admissions over permanent settlement. This is typically seen in its economic "demand-driven policy" where the demand for workers and the abundance of their availability drives the industry (92). Silverman and Hari (2016) compared this policy to sex trafficking where the issues of consent, choice, and coercion are comparable. The level of unfreedom that exist within these two domains enables the participants to be discriminated against. In the SAWP case, coercion to work is hidden rather than visible as it showed a willingness to go the extra mile, increasing the chances of favorable evaluations and possible future return. Thus, 'freedom' exists in theory, but it is less defined in practice. First, the uncertainty of daily crop yielding meant that a worker could be called to harvest on off days and if absent, mental notes on the employer's part of reliability are perceived. This mental note is then reflected back unto the worker, in the form of not being called back the next season. So, in this sense, an 'unfreeness' exists for the workers. A conservative analysis to this unfreeness is the worker themselves whom through these factors, 'choose' to make themselves available for work at all times. With a maximum eight months to earn money, if the worker is not available for work, even on his/her own time, it means that task and pay go to someone else and the worker effectively earns less. In addition, overtime is usually not paid for hours of work so the less time these workers are available, in addition to being 'unreliable' to the employer, the less they earn and with the set-up of the program- a sense of unfree labour persists. (Beckford 2016). 
With all the global social benefits touted by migration, the fear of an open border persists for policymakers and the electorate in high - income countries. Especially concerning is the permanent settlement of unskilled workers that can result in an economic burden on the social programs in these high-income countries. Moreover, the political backlash from the electorate resulting from the threat of permanent jobs from citizens of these countries, even though jobs in areas associated with temporary foreign worker programs such as the SAWP is avoided like the plague. Ironically, this fear only seems to be present in lower -skilled permanent settlement, rather than the higher skilled, giving the impression that with the high level of education, citizens in these higher income countries would not find issues securing positions that require higher levels of education and employment. Moreover, there is the wide perception that temporary migration is favored by civil society over permanent migration because of the lack of threat 'temporariness' provides (Basok 2007; Hennebry 2012). It is feared that permanency would make jobs scarcer and should these workers transition to permanent residence, they would refuse to remain within the agricultural sector as did other participants prior to the SAWP (Basok 2007).

Though the Caribbean was the initial locale for recruitment under SAWP and continue to send recruits through SAWP to Canada, most of the literature concentrates on the Mexican representation and perspective and to a smaller extent the Jamaican experiences. While the views held within the literature can transcend all sending countries, there is a gap in knowledge of the experiences and geopolitical viewpoint of the other individual source countries - most of whom are in the Eastern Caribbean. My research can contribute to the existing literature by examining the role of source countries in maintaining the program in its current 'temporary' state. 


\section{Impact of circular migration in of the Seasonal Agricultural Worker Program}

\section{management}

There are strong arguments among advocates and scholars on circular migration. International organizations such as the Global Commission on International Migration (GCIM), the International Organization for Migration and the European Commission, support circular migration as a progressive migration policy with triple-win capabilities (Castles and Ozkul 2014). Triple- win as the benefits through its management are seen for the Canada, the source countries and the participants in the program. Most circular migrations patterns are government sanctioned and are usually built into migration policy framework of both source and receiving countries (Ruhs 2016). It can encompass both voluntary and the involuntary individuals, involuntary in this sense meaning the lack of work choice, since the employment conditions in their home countries are dismal.

Circular migration is viewed among its proponents as the new rage in international policies since it seen as a driver of development through remittances. It is theorized that the remittances gained from employment in high- income countries can contribute to social stability and economic development to developing countries (World Bank 2006: iii). Through remittances, 'transnational' families can earn abroad and consume at home, which is possible through the steady flow of work provided in industrialized high-income countries, contributing to development through the stimulation of business activities. Vertovec (2007) points to the role remittances play as a major component of global economic resources. The result is the push by international organizations to encourage source countries' diasporas contributions to this new source of economic resource. It also propels these states to encourage and agree to managed programs such as the circular migration example of the SAWP. Thus, these temporary migrant programs have been rising on a 
global scale with $4 \%$ to $5 \%$ estimated increase of temporary foreign labor by high- income countries (Basok 2007). Flexibility in the labour market and appeasement of the electorate concerned with permanent migration are reasons for the growth in TFWP.

However, circular migration is disastrous for family and nation-building, since the males in the household are usually the ones seeking employment, leaving many single parent femalesrun households (Constant \& Zimmermann 2010). Circular migration results in the sociological failure of the family relationships consequential in marriage breakdown and alienation of children from parents. Even though they are touted as 'win-win' programs, circular migration policies also have negative (intended and unintended) consequences. Among the negative consequences of circular migration policies is their potential for migrant exploitation. This exploitation is seen even in programs touted as 'best practices' and regulated by states and international regulatory organizations. Exploitation in the sense that while the freedom of choice theoretically exists, practically the same is less linear. In this case, to argue that these workers entered into contracts on a voluntary basis through no coercion on the parts of governments or employers seem too simplistic an analysis. The exploitation is manifested in the treatment of the workers, with both governments and employers fully aware of the labour scarcity facing participants in circular migration programs. Temporary migration programs whether regulated or unregulated, subject individuals to numerous forms of precarity, distinguishing their experience to an extent from those of local individuals in the receiving country.

Piper et. al (2017) argue that official adoring of the status of migrant in certain sectors of the labour market increases the level of precarity which in turn manifest the issues of inequality and injustice. A result of which allows national and transnational institutions concentration on technical and bilateral agreements at the expense of migrant rights (Piper, et. al. 2017). Migrant 
rights and temporary migration policy frameworks need to go hand in hand, however, viewing migration from a rights-based approach has the potential of negative consequences, such as further restriction to immigration policies (Ruhs 2016). This can lead to future candidates to the program been denied thus directly affecting the livelihood of these individuals and their families. Piper, et. al. (2017) examine precarity where the distinction of the perception of precarity between the Global North and the Global South are distinctly visible. In this they emphasize that due to the historical capitalist development within Asia and the global North, migration linearity into precarity or how migrants become precarious is not evident. Rather, it is the existing unstable conditions in the home states that lead to migration in the first place and these movements are framed by present and past uneven development. As such precarity of economic marginalization is what drives migration.

Additionally, the touted development capability of temporary migration encompasses a more long-term strategy since, income accumulation, if achievable, is only possible after several overseas stints. Piper et. al (2017) argue that this 'is a specific form of protracted precarity' where its 'selling point' features of unlimited labour supply and reliability for development is at the expense of migrant rights. Hence, circular migration might be an appropriate tool for conceptualizing migration theory rather than a tool for policy prescription (Skeldon 2012). Support for this position is quite persuasive, given the extensive time migrants would be required to be away from their families to make any lasting impact on development. An illustrated example is taken from the Seasonal Agricultural Workers Program, where the continued circularity of individuals can last more than 20 years in many cases pointing to its unsuitability as a policy framework. The actions of source countries towards their citizen in the event of a complaint or injury always plays a role in the norms of exploitation of the workers. 
While international circular migration has had very negative public feedback usually centering upon the exploitation and unfreedom of the workers, Hugo (2013) posits that this reaction lay with governance rather than the program and allude that the program can have positive outcomes. Similarly, acknowledging the immigration policies of high- income countries Ruhs (2016) argues that pushing for more rights while necessary since the treatment of these workers is subpar to that of a Canadian citizen or permanent resident; this push has the adverse effect of restrictive admission policies in that with more right come greater restriction of who can enter. As such, programs like circular migration become models that countries adopt to economize their labour supply at the expense of the workers in these programs. 


\section{CHAPTER 3: METHODOLOGY \& DESIGN}

Methodologically my main tasks have been to explore the role of source countries in the SAWP and whether through these roles they have any weight or say in maintaining the continuation of the temporary status of the workers. Following Creswell (2014), I agree that while research approaches should not be viewed as rigid structures. Hence, through data collected individuals in St. Vincent and the Grenadines, I analyse interpretations of the state's role in the SAWP through general themes achieved through a qualitative research approach. A study tends to be more qualitative when it used to explore and understand the meanings people attach to a social problem.

Through semi-structured interviews in St. Vincent and the Grenadines, and secondary sources which include academic, government data and non-scholarly media publications, I made observations about the hidden and visible involvement of source countries in the shaping and reproducing of the SAWP and briefly state my position as a researcher. In the two preceding chapters I discussed the conceptual framework of circular migration to facilitate a discussion of source countries in general and embraced an exploratory approach for St. Vincent and the Grenadines in particular. The proceeding three chapters discuss the findings from the interviews and the analysis of the secondary sources.

\section{Summary of the Field Methodology}

This section outlines the process taken to locate the participants for the research study after permission was granted by Ryerson University Research and Ethics Board. It also outlines the timeframe of the interview process with current and former government workers in St. Vincent and the Grenadines as well as current and former workers of the SAWP. Finally, it outlines the steps taken in the research method prior to conducting the interviews. 


\section{$\underline{\text { Locating interview participants }}$}

After obtaining permission from Ryerson University Research and Ethics Board (REB), I travelled to St. Vincent and the Grenadines where I piloted semi-structured interviews with 10 participants for six weeks from mid- May to mid- July 2019. Through a purposive snowballing technique, I recruited a total of five former or current workers of the SAWP as well as three former and two current bureaucrats that manages the program. One SAWP worker was recruited by word of mouth; explaining the details of the research and what could be some of the potential benefits of participating in the research. I provided my contact details to the individual which was shared with other current and former workers. To recruit current bureaucrats, I approached the Department of Labour explained the purpose of the research and sought their permission for interviews. Interviews were then conducted with two Senior officials from the Department of Labour: The Deputy Labour Commissioner (ag) and the SAWP program specialist. I recruited former bureaucrats involved in the program by researching their contact information, then contacted them explaining my research project and requesting their participation.

\section{The interview process in St. Vincent and the Grenadines}

I spent three weeks interviewing current and former bureaucrats at the Ministry of Labour in St. Vincent and the Grenadines. Had it been possible this paper, ${ }^{14}$ could have been strengthened by speaking directly with the Minister of Labour in St. Vincent and the Grenadines to capture his viewpoints on the program and what it means for St. Vincent and the Grenadines. Also had it been possible, spending more time at the Ministry of Labour office would have aided in being able to interact more with the officials interviewed, rather than in the time pressed way in which the interviews were conducted. However, during the interviews with both current and former

\footnotetext{
${ }^{14}$ St. Vincent and the Grenadines was granted a seat on the United Nation Security Council, at the time I was conducted my research, making it impossible to speak with government officials as originally planned.
} 
bureaucrats I spent several hours daily - Monday through Friday - talking about recruitment strategies, the general procedures they specifically adopt to send workers to Canada and, their feel and experiences with the program. The interviews with current and former bureaucrats took place at the Ministry of Labour office in St. Vincent and the Grenadines and at the National library, located in Kingstown, the capital city of St. Vincent and the Grenadines. The bureaucrats interviewed were males and female.

I also interviewed current and former workers: two females and three males whose work experience in the SAWP ranged from two seasons (eight months each season) to ten seasons (five weeks to eight months each season). The three males all worked on farm in Ontario, while the females worked on farms in New Brunswick and British Columbia. Interviews were conducted over a three-weeks period and I met these individuals at various community shops or the public library. These locations were chosen by the workers for reasons such as proximity to their homes, their familiarity with the location, and their general comfort with the meeting location. Former workers who took part in SAWP were included in interviews for three reasons: (1) their knowledge of the program and why they have chosen to end their participation; (2) for some reason was not 'invited' to continue participating in the program, or (3) because the former workers may feel freer discussing the negative aspects of the program and their treatment (protection or lack thereof) by their own government.

I did not interview current civil servants who hold a lower position in the Ministry because of the perceived higher risks to these individuals, such as intimidation regarding repercussions and potential loss of employment should information potentially critical of government policies and practices about the program be shared. I rather decided to interview those currently working in mid-high positions for the government and retired bureaucrats of the program. The information 
given by current government workers with a mid-level or senior position might be perceived as defensive of government policies since most mid-level and senior officials are government affiliated. This was balanced against the information from retired bureaucrats who may be more independent and open; may have had more time to reflect over things; and may feel more comfortable to talk. Additionally, current and former bureaucrats interview responses are paraphrased or quoted as civil servants 1 through 5 to maintain the confidentiality of the two current bureaucrats. SAWP former workers interview responses are paraphrased as former worker 1 or 2 and current workers are quoted 1 through 3 since the identity of the former and current would not be easily identified.

Prior to conducting the interviews, an approved list of tentative questions was compiled to guide the interviews and I meet individually with all of the participants and explained the consent agreement. The participants were informed through the consent agreement of their right to decline response to any of the questions. They were given the opportunity to review the consent agreement after which I reviewed the consent agreement once again to ensure it was understood and to clarify any questions or concerns before conducting the interviews.

Interviews were audio-recorded when the participants provide their consent to being audio-recorded. The participants who declined being recorded, their responses to the interview questions were hand written in a note pad. Notes taken during the non-audio interviews were analyzed immediately after the interviews to maintain as much of the originality of the interviewee's spoken word. Throughout the interviews with all of the participants I was thoughtful of the need to conceal their identity, and considerate of how or whether they wanted me to include their contributions in this paper. From the responses collected in the individual face-to-face interviews, I then developed themes that could both be generally applied to source 
countries within the program and/or treated as particular to St. Vincent and the Grenadines.

\section{$\underline{\text { Secondary Sources }}$}

Secondary data is useful for this research in order to understand the nature and history of the SAWP. Given the lack of information on the role of source countries in the SAWP, reviewing secondary data material did not provide the specific information required to answer the research question: Does the government policy of source countries in the SAWP has any weight in the maintenance of temporary immigration status of the workers in the program? Literature reviews in an exploratory research are carried out to demonstrate that little or no work has been done on the group, process, or activity under consideration and that an open-ended approach to data collection is, therefore, wholly justified (Stebbins 2001). For the review of the literature, first, I searched for the studies that came closest to examining the roles of source countries in the SAWP. I then examined how these studies leave unexplored certain aspects of the phenomenon (Stebbins 2001).

\section{$\underline{\text { Researcher's Position }}$}

My own experience as a former foreign worker shapes the way I investigate precarious work and immigration status. I examine issues of marginalization, specifically in labour migration through a transformative worldview perspective by providing a voice to the participants on how their own source country government is culpable in their marginalization. A transformative worldview perspective places central importance on the lives and experiences of the traditionally marginalized with particular emphasis on, inter alia, "the socioeconomic class that result in asymmetric power relationships" (Creswell 2014 citing Mertens 2010). It uses a program theory of beliefs about how a program works and why the problems of oppression, domination, and power relationships exists. Moreover, research in transformative worldview links both political and social action to these areas 
of marginalization (Creswell 2014 citing Mertens 2010). The particular area of marginalization I examined is whether the Vincentian state, a source country in the SAWP is implicated in not enabling workers to have pathways to Canadian permanent residence.

I empathize with conditions of precarity in residence status and the various socio-economic and psychological issues that accompany this status. Berger (2015) posits that there are benefits and challenges to a researcher's social position, personal experiences and political and professional beliefs when the researcher shares the position and experience of those they study. She argues that reflexivity is the process where the researcher turns the research lens on one's self to recognize and take responsibility for the research situatedness within the study. There is a relationship to the setting(s) and people which includes the questions being asked, the data collected and the interpretation of the said data (Berger 2015). For example, in this study, I am aware and sensitive of checking my biases towards temporary foreign worker in order to present the findings objectively. Supervision and a subsequent second reader of the research finding will provide strength to the final presentation of the findings. 


\section{CHAPTER 4: FINDINGS}

The main research question in this study is about roles source countries play in the governance of SAWP and whether through these roles they have any weight or say in the workers not being able to transition to permanent residence. First, it was found that for the Eastern Caribbean countries participating in the SAWP, there is a unique process in the distribution of vacancies for migrant farm workers. Due to a separate agreement between the OECS member states, individual source countries in the Eastern Caribbean do not approach employers or F.A.R.M.S directly. Unless a specific Eastern Caribbean country request is made by an employer, vacancies are cumulative for the entire OECS states and are distributed among the states involved in the SAWP by the liaison office in Toronto. Additionally, there is a discretionary recruitment process for SAWP workers in St. Vincent and the Grenadines after the state receives its number of positions to be filled from the liaison office in Toronto. The recruitment process supports maintaining the SAWP in its current 'temporary' form through the invisible and perhaps unintended policing of the Canadian borders from the outside and monitoring the movement of its citizens inside the Canadian borders.

Moreover, the bilateral agreement of the MOU between the receiving and source countries create and reproduce a state of dependency of SAWP workers on the program. Likewise, the control (or lack thereof) of remittances by the state in St. Vincent and the Grenadines help reproduce the temporary nature of the program by punishing workers unable to repay flight loans upon being re-called by the program. Finally, the lack of interest by the Vincentian Government in protecting and improving SAWP workers' rights contributes significantly to the current issues contributing to the 'temporary' of the program. In the first section, I present the findings under five themes that emerged in the interviews. In section (ii) I discuss the findings in light of the 
research question. In section (iii) I provide policy recommendations based on the findings and subsequent discussion and analysis.

\section{(i) Research Findings}

\section{SAWP farm worker vacancy allocations in OECS participating member states}

Farm vacancies for SAWP workers are cumulative for the entire OECS states. These vacancies are then distributed among the participating states by the liaison office in Toronto unless an employer makes a request for workers from a specific Eastern Caribbean country.

According to interviews from former and current bureaucrats, a vacancy list called a "priority list" indicating the number of vacancies for the upcoming season is obtained from the Liaison office of the OECS in Canada. The source countries in the Eastern Caribbean do not have direct or formal contact with the farm employers or the Canadian administrative body (F.A.R.M.S.) as individual entities. The $O E C S$ is responsible for the distribution of vacancy to 8 out of the 10 member and associate member states in the organization namely: St. Vincent and the Grenadines, St. Lucia, St. Kitts and the Nevis, Antigua and Barbuda, Grenada, Montserrat, Anguilla, and Dominica. St. Vincent and the Grenadines currently supply workers for the majority of the vacancies. However, the total number of farm worker vacancies for the entire OECS becomes public in the annual review meeting attended by all OECS member states in the program.

During the interviews with civil servants, the estimated figures quoted for the 2018 season were between 356 and 360 vacancies for St. Vincent and the Grenadines; whereas St. Lucia followed closely with an estimated figure around the 330 mark for season vacancies (civil servants \# 1, 2, 3). The distribution of workers in the program for the OECS countries is interesting since in numerous cases, employers would specifically request Vincentian workers to 
fill vacancies or St. Lucian workers etc. In these instances, the request of the Canadian farm employer takes precedence over the distribution approach from the OECS Liaison Office in Canada. For example, one civil servant noted that sometimes farms do ask specifically for workers from a particular OECS state or "sometimes they just send the vacancies to the liaisons office and say they are looking for some Caribbean folks and then they would do the distribution. Give me two from St. Vincent, give me two from St. Lucia etc..." (civil servant interview \#5).

Having a system where source several countries interest is represented by a single body as illustrated by St. Vincent and the Grenadines and its relationship with the OECS enables the temporary nature of the program. it prevents smaller SAWP producing states from presenting their concerns directly to F.A.R.M.S. where decisions can be made outside the OECS. Contrastingly, hiring and vacancies could have been made by workers directly to farm employers at the US border for Mexican workers under the Bracero program resulted in less control of the program by the government of Mexico. The union of the OECS retains control over the hiring process and vacancy allocation as a single body by maintaining direct access to F.A.R.M.S. on behalf of its member states.

\section{Discretion in the recruitment process for SAWP workers in St. Vincent and the}

\section{Grenadines.}

In practice, high officials in St. Vincent and the Grenadines have discretion over who is allowed on the program through the requirement for two guarantors in the recruitment process. This particular policy of having a guarantor who holds a significant position in St. Vincent enables the Canadian Government to better police its borders with greater control over who gets to come and leave at the specified time. Recruitment of workers starts and ends in November each year. Individuals interested in the program fill out the application form at the Department of Labour 
located at Murray's Road in Kingstown. The sign-up period is announced over the radio and on the national television station SVG TV. However, a lot of individuals interested in the program know when it is time to sign up (workers and civil servants' interviews). St. Vincent and the Grenadines receives the priority list from the Liaison Office in Canada early December and old workers including those who have been 'named' by their Canadian farm employer are processed before any new worker is taken from the shortlisted applications.

For an application to be considered, potential recruits must provide two letters of recommendation from prominent members in society. In all cases these 'references' are either civil servants holding parliamentary positions or other reputable positions such as a lawyer or Justice of the Peace. Without the two references an application for recruitment under the SAWP remains incomplete and it would not proceed to an interview selection. The requirement for recommendations from reputable officials or professionals in the source country is significant in terms of the pressure places on the worker to return to St. Vincent and the Grenadines. Those workers successful in gaining a place on the program have a kind of 'duty' to return to the source country because they did not want to offend or shed a bad light on the referee (workers and former workers interviews).

There is always an overflow of applications for work under the SAWP, usually about 1500 at the end of the sign-up period. The overflow of these applications is destroyed at the end of each recruitment period (Civil servants' interviews). One former SAWP worker claimed that "a lot of applications get ripped up as soon as the people leave them at the office; the application is not even considered!" (former worker interview\#2). Most potential recruits obtain recommendations from ministers in the government (workers and former workers interviews). 
While all bureaucrats rejected the idea that they specifically chose workers on recommendation of government officials or individuals with high-ranking status, all five participants of the SAWP alluded to being chosen for the program because of their affiliation to someone with connections to the program whether a high-ranking member in the state or a Minister in the government. According to all of the workers and former workers of the program, had it not been for the person(s) who recommended them, or for them having some kind of a "pull-string" 15 they would have never been chosen for the program. In one interview, the participant revealed applications of potential recruits being torn up and placed in the garbage, while the applicant genuinely thought s(he) had a chance of being recruited (former worker \# 2). One participant questioned me in detail regarding whom I worked for and whom I knew prior to agreeing to the interview. The concern of the participant was saying anything that would identify him/her since $\mathrm{s} /$ he was awaiting a call back to participate. The call back was based on the intervention of individual(s) extremely close to the program, hence the worker wanted to ensure that by participating in this research project his/her chance of going on the program once again would not be jeopardized.

A civil servant (interview \#2) stated that during the interview process for new recruits (s)he is looking for signs that the potential worker is not using the "program as a means of escape." When asked to explain what was meant by using the program as a means of escape the civil servant responded:

[...] you not even incline to do any farming here you going to make me start thinking, are you genuinely wanting to go to Canada to work? Or you want me to process you so that you can use the opportunity to run off?

\footnotetext{
${ }^{15}$ Having connections in the office or connections with someone who knew someone closely associated with the program
} 
The official went on to explain that his/her job is to ensure that people genuinely wanted to go on the farm program, and they were not going to use the farm program as a means to escape from St. Vincent and reside 'illegally'- [undocumented]- in Canada making it difficult for St. Vincent and the Grenadines send more workers on the program.

Most civil servants interviewed indicated that in the case of 'jumpers' ${ }^{\text {'16 }}$ the office in St. Vincent and the Grenadines sometimes became aware of the incident even before the formal paperwork of the incident is recorded and sent from the liaison office in Canada. In these cases, other workers on the same farm or farms in close proximity with each other would inform their referee or the office. In one case a referee advised that (s) he had only had "two run offs ['jumpers']" for the ten-odd years (s)he had being recommending persons to the program. The referee was still somewhat upset that these individuals had 'spoiled my good record [and] it was best I had sent someone else" (civil servant interview \#2). In another case, a referee had gotten wind that someone s(he) recommended had 'jumped', however when the referee contacted the worker, $\mathrm{s}(\mathrm{he})$ was advised by the worker that (s)he had just visited family in Canada and is now back on the farm. The guarantor process allows the source country by proxy to manage and curtail the actions of its citizens by ensuring they adhere to the stipulations of the temporary work visas issued by Canada.

\section{Memorandum of Understanding and the creation and reproduction of dependency on}

\section{$\underline{\text { SAWP }}$}

Through the MOU and the naming of some workers by the employers in the program, source countries including St. Vincent and the Grenadines, treats the SAWP as a source of 'permanent employment.' In treating the program as a source of 'permanent employment', the government

\footnotetext{
${ }^{16}$ The term is used in Canadian immigration visa office memos to refer to individuals granted temporary residence in Canada and do not leave at the end of the temporary residence visa exit date (see Satzewich 2015)
} 
of St. Vincent and the Grenadines treats the period of no-work under SAWP as a 'vacationperiod' since most of the workers are 'named' or recalled as outlined in the MOU agreement.

All of the participants interviewed said that the program provided financial gains for the workers and their families even though it requires most SAWP participants spending the majority of their time in a foreign country. Given the high rate of unemployment in St. Vincent and the Grenadines, the SAWP is viewed as a 'permanent' worker program in the country even though this program operates under the TFWP in Canada. One former bureaucrat described this 'permanent' work kind of mentality through the 'naming' mechanism of the MOU. It was noted that once a worker performs well and has a good relationship with the "boss that worker could very well guarantee the boss would send his/her name down for the next season and so forth" civil servant \#5). This practice of naming and recalling workers consecutively over the years coupled with the workers splitting time in the receiving and source countries is well documented in Hennebry's (2012) work “Permanently temporary? agricultural migrant workers and their integration in Canada." Since some participants are confident they would be recalled or 'named' by the Canadian employer most participants under the SAWP - from government bureaucrats' perspectives - feel a kind of superiority when they return to St. Vincent and the Grenadines and would await being recalled to the program in another three to six months instead of looking for work in the meantime upon their return (civil servant interview \#4). Moreover, the workers who participated in the program over a number of years are perceived as using the one to three months between being recalled as a vacation period until it time to go back to Canada (civil servant worker interview \# 4).

While the workers praised the program for providing an income, they use to send home for their families, most talked about the difficulties they encountered when seeking employment after 
their return to St. Vincent and the Grenadines. SAWP workers and former SAWP workers explained that employers are unwilling to hire farm workers returning from Canada because they see them as unreliable since in most cases they would return to Canada for the following seasons (worker interviews). Most former workers and current workers explained that they usually have to resort to self-employment to suffice with hopes of being re-called. They would do so by either farming plots of land they have and selling the produce in the markets on the weekends or some of them would purchase clothing and other small household products in Canada and re-sell these items upon their return to St. Vincent and the Grenadines in order to provide an income.

The loss of control over remittances for the government and its effect on Vincentian SAWP workers.

There is no proactive provision by St. Vincent and the Grenadines to assist workers without remitting a portion of the SAWP workers salary. Source countries explain that their inability to remit part of the worker's salary prevents them from assisting workers, in some cases, to return to Canada for work under the program (civil servants' interviews; Wright 2018). On $1^{\text {st } J a n u a r y ~ 2016, ~}$ the Canadian Government stopped the practice by source country governments of withholding $25 \%$ of the SAWP workers incomes (Wright 2018).

Bureaucrats in St. Vincent and the Grenadines advised that when they were able to withhold $25 \%$ of the workers' weekly pay, workers benefited. For instance, the withheld salaries were used to pay back any monies owed by the workers for their flights, in the event the flight balance was not fully repaid from their weekly deductions in Canada. If workers did not owe any money, then the entire balance withheld during their time in Canada was given to the workers upon their return to St. Vincent and the Grenadines. 
Officials in St. Vincent and the Grenadines advised that the loss of the withheld salary places an extra burden on the Department of Labour Office, also resulting in a disadvantage to some workers (civil servant interviews). Officials noted that with the lack of funds in the workers account, in some cases the workers do not have enough money to pay for the cost of the return flights to St. Vincent and the Grenadines. In these instances, should the worker be called to participate in the program in subsequent seasons, the monies owed would have to be repaid before the worker is given another chance on the program. The loss of control over $25 \%$ of the worker's salary remitted to source country place some workers under the SAWP in a position where they either have to borrow monies to pay their return flights paid in advance by employers or forfeit the chance of return to Canada under the program. In one instance, a civil servant suggest that the government can control this by advocating on its citizens' behalf to have employers subsidized the cost of return flights when they request shorter terms of employment from migrant workers. Another way would be for the Vincentian Government to absolve this cost, since the program allows its citizen to find employment the state could not otherwise provide (civil servants interviews).

While the measure to stop the withholding a portion of the workers' salary was lauded by advocates in Canada, in St. Vincent and the Grenadines, evidence from the interviews show the action to be a catch -22 since the workers suffer in both instances. In the first instance, the worker faced the arbitrary withholding of their salary and in the latter since they now have no savings upon their return home, they may not be able to return on the program if unable to service ticket debts they might have accumulate in the previous season. 


\section{The lack of interest by the Vincentian Government in protecting and improving SAWP}

\section{workers' rights}

Although the uniqueness of the Treaty of Basseterre requires a representative of the OECS for all Eastern Caribbean source countries, at least two civil servant interview participants lamented the invisibility of the Vincentian state at annual meetings. Specifically, the bureaucrats denounced the government of St. Vincent and the Grenadines lack of interest in the program. When talking about the position of the government of St. Vincent and the Grenadines on the possibility of SAWP workers being able to transition to permanent residency in Canada at some point, one bureaucrat replied:

[...] honestly --- I'm going to be honest here --- I don't think that the government is into the depths of the farm program. I think they are seeing it as just accepting some worker to Canada and we are looking good here.... but the depth of the program they don't get involved in it unless they want somebody to go on the program [...] (civil servant interview\#5).

According to the civil servant, this lack of interest by the government in the workers' welfare makes the workers feel unappreciated by their own government and therefore, they [the workers] have no expectations from the Canadian Government. The bureaucrat explained that though there is no formal communication between source countries and F.A.R.M.S. or the farm employer, other source countries do find ways to be directly involved in the program and also to make their citizens under the program feel appreciated. An example was given where "some other countries offer their farm workers stuff like duty-free concessions when they come in, we don't do that..." (civil servant interview\#4). Yet another bureaucrat, corroborated this observation about the government's lack of interest in the program when making comparison with another OECS SAWP participant:

[...] look for example St. Lucia, St. Lucia takes a delegation every year with the Minister of Labour [exclaimed in an awe voice with raised eyebrows]. to Canada, so they meet with their workers, they meet with their employers, they interact with them, so you are no 
longer in this massive meeting at the end of the year alone. You go prior to the meeting so when you sit in the meeting you have more knowledge of what is going on and because of those visits St. Lucia would have been getting increased vacancies. you are there with the minister and the persons involved in the program and the employers can say yes, they're showing interest so[...] (civil servant interview \# 2).

This observation about the government's lack of interest in the program was shared by the workers and former workers. One worker brought the contract signed in 2018 to substantiate the difference between what was signed and what continue to be the actual reality of working conditions. For instance, the contract stipulates that the worker should be paid for at least three hours of work in the event that the worker is called to work. In all instances the worker explained that (s) he was never paid for three hours when the "boss" only wanted an hour's work. In another instance, the worker explained that the MOU specifies that the living quarters should be inspected and must meet Canadian housing standard. In many instances the place does not have heating and the water remains undrinkable. These issues were never addressed with the liaison office by the worker because:

I am in a minority so if I go there and try and change things is me alone and then I will be without a job... they will get rid of me and all six guys in St. Vincent [is] waiting for my job tomorrow.... so that is basically one of the reasons I never raised it because is like I am fighting against the world me alone [...] (current worker \#3).

In another instance, SAWP workers talked about some farm employers showing more interest in them than the liaison or the government of St. Vincent and the Grenadines. For example, one participant praised the humanistic treatment of one farm employer in New Brunswick allowing her to attend her daughter's wedding in Toronto:

I asked for two weeks when she get married and the boss tell me ... "oh go ahead no problem." I spent the two weeks and he self carry me to the airport and he self, come back for me. I find that was a good thing [...] (former worker interview \#2). 
Thus, even though Canada has greater control in providing migrant farms workers under SAWP with a pathway for permanent residency if it so chooses, the findings from St. Vincent and the Grenadines show that source countries also play, at least indirect and unintentional, roles in the program's longevity as a temporary labour migration program through its recruitment practices and the lack of interest for its SAWP workers wellbeing. In some cases, the source country provides a policing mechanism for the Canadian borders; and in other cases - gathered through the interviews - they extend no effort to require residency changes to the program.

\section{(ii) Discussion and Analysis}

The evidence gathered through the interviews does not suggest that the government of St. Vincent and the Grenadines deliberately try to keep their citizens under the SAWP as temporary labour migrants in Canada - or does the evidence gathered suggest that the government knowingly dissuade or try to prevent their citizens from accessing or seeking - a pathway to permanent residence. On the basis of the interviews conducted, it seems as though the government of St. Vincent and the Grenadines view its role as just hiring officials to find workers for the SAWP in Canada. However, investigating into the welfare of its citizens does not appear to be on the agenda of the Government. The Vincentian Government seem to rely solely on the service of the OCES and pass all the responsibility for the treatment of its citizens to that management body.

Comparatively, Canada has done the same thing when it relinquished oversight of the program to F.A.R.M.S. in 1987 (Andre 1990). For its part, the Canadian Government in relinquishing its oversight only grant visas to the workers under the program, having transferred the administration of the program to F.A.R.M.S. The difference between the Canadian relinquishment and the source country leaving the liaison in complete control is that the Canadian state still satisfies the demands of its citizens (specifically, the needs of the farmers for agricultural 
workers) by issuing work visas under the program. The Vincentian Government, on the other hand, leave its citizen feeling unappreciated and unprotected by their state.

The recurring sign-up for workers in the recruitment phase of the program does not support potential workers under SAWP. This recurring sign-up process gives new applicants the false sense of hope that could have an opportunity of employment under the program. In this way, the citizens of St. Vincent and the Grenadines provide a reprieve for the government during the recruitment time in the form of less complaints about unemployment since the potential recruits feel their application could be selected for employment. As all participants interviewed stated, a high number of prospective workers show interest in the program each year.

Instead of conducting a recruitment call at the end of each season, potential new recruits can be taken from the already existing lists. This would provide a more realistic outlook to potential recruits of their chances of being selected for employment under the program and also forces the government to tackle its own unemployment numbers instead of factoring potential employment provided by SAWP ---- even though this work is 'temporary.' Currently the list is destroyed at the end of each season and the recruitment process starts afresh in November. The SAWP worker numbers are currently counted in the yearly employment report in St. Vincent and the Grenadines (civil servant interviews), therefore. the government uses the program as a positive factor in its employment forecast.

Another observation from the analysis of the interviews is tied to the nature and implications of the MOU. The MOU spells out the 'partnership' between the source and receiving country, and roles source countries are expected to play in assisting Canada police its borders from abroad. It does so by scrutinizing who is allowed on the program and regulating the departure of individual at the end of their visa. The regulating role expected to be played by source countries is 
explicit in the F.A.R.M.S. participating countries comments (2019) in Trinidad and Tobago: "[t]he Labour Liaison Branch will not support or encourage workers extending their stay in Canada for personal or recreational reasons after completion of their contracts." Even though the visa issued by the Canadian Government on the surface legally allows the workers to remain in Canada until December 15 each year, employers are reminded by Trinidad and Tobago that "flights for workers are booked no later than the $5^{\text {th }}$ day after the last day of work" (F.A.R.M.S. participating countries comments 2019). This request specifically shows the systematic role the source country plays in curtailing the movement of its citizens under the program. Work on the farm is sometimes completed prior to the December 15 temporary work visa expiration. By insisting workers leave no later than 5 days after the last day of work irrespective of the visa expiration date, the source countries assist the Canadian state in policing its borders without the involvement of Canadian border patrols. Requesting reputable referee is also perceived to encourage workers' return to the receiving country at the end of the season contract. In essence, having a referee potentially lowers the risk of Vincentian farm-workers 'jumping' or remaining in Canada after the end of the season and the expiration of their work visa.

Through the bilateral country agreement, the source country's own legitimacy and reputation are placed at stake. Thus, should the source country send migrant farm-workers who subsequently breach the contractual agreement and remain in the receiving country, the reputation of the source country is called into question. The issue of government legitimacy then becomes a concern since the possibility exists that citizens of the particular source country would not get the opportunity to participate in the program. If their citizens lose the opportunity to participate in the program, source countries already facing challenges of rising unemployment could in fact face labour unrest and potential loss of legitimacy and power by their governments. 
According to Vincentian SAWP workers the main reason for participating in the program is the lack of employment in their homeland. Hence, this program provides them with an avenue to be employed even though it requires them to be away from their families for an extended period. Once they become part of the program the desire to remain employed often triumphs the desire to better their employment condition from temporary to permanent since they feared expressing such desire would lead to them be taken off the program. Moreover, they lament the perceived absence of interest in the program by the Vincentian government. To this end the workers adopt an attitude of indifference towards their overall treatment in the program and less interest is shown in challenging the circular pattern of their employment over the years. This is a result of the systemic role played by the Vincentian government in maintaining the temporary nature of the program. An analysis from the responses provided by civil servants also support the belief that the disinterest shown by the government in the program dissuades the workers from struggling for pathway to permanent residence since their own government does not show interest in their well-being.

\section{(iii) Policy Recommendations}

The longevity of the SAWP program coupled with the fact that it still remains a temporary foreign worker program without access to permanent residence suggest the need for an overview of the MOU which governs the contractual relationship between the receiving and source countries and their relationship with farm-workers and farm employers. Based on the voices of current and former migrant workers, we see that both receiving and source countries play a role in restricting the rights and freedoms they have in the program. The program would benefit from open work permits being granted to participants from the onset of their contracts, thus allowing workers to leave bad employers and forcing employers to uphold the contractual agreements stated in the MOU. 
Specifically, participants mentioned source country government anonymously following up with the workers once they return from working in Canada as a way to find out what they like or dislike about the program. A few stated that a survey should be provided at the de-briefing upon return to the home country. Such measures could improve the relations with Canadian Farmers as well as F.A.R.M.S. - the administrator of the program on behalf of the Canadian government. Based on recommendations made by at least eight of the participants, source country government needs to be more involved in the program, but this would have to be a collective effort by all the source countries in the program. This suggestion was made in light of the competitiveness of the program as each of the participating countries outside of the OECS aggressively seek new farms each season to send migrant workers. Involvement in the program, could be source countries collectively desisting from policing the Canadian borders. Instead, focusing on ways that can aid the workers in exiting the circular migration programs such as SAWP.

Should source countries recuse themselves from acting as external border securers, Canada would have to implement other measures to ensure agricultural workers leave at the end of their stipulated employment terms. Measures could include providing pathways to permanent residence for SAWP workers. Providing pathways to permanent residence would ultimately improve the workers' working conditions and treatment under the program. Farm employers would also benefit substantially as a pathway to permanent residence would hold them accountable to workers treatment and conditions since the workers can openly trade their service. In this way, farm employers would be able to attract the best with decent living and working conditions. 


\section{CHAPTER 5: CONCLUSION}

The main concern of this Major Research Paper has been to examine whether the government of St. Vincent and the Grenadines has any role in maintaining the temporary nature of the SAWP. It specifically focused on the lack of a pathway to Canadian permanent residence for these workers. The recruitment process in St. Vincent and the Grenadines, supports the supposition of source countries role in maintaining the temporary nature of the SAWP. Imposing criteria such as prominent referees for potential and eventual recruits to the program results in the effective policing of the Canadian border by the source country.

Moreover, the requirement of recommendations to the program by prominent members of the Vincentian state reduces the likelihood of the workers overstaying the time they are allowed in Canada. Within the framework of providing work for its citizens, the Global South dependency on circular migration. It is easy to forget that mechanisms adopted to ensure effective administration of circular migration programs such as the SAWP, adversely affect the workers. The responsibility for workers' rights, living, and working conditions not only lies with the receiving countries but also the source countries that send these workers. Through its recruitment process, the Vincentian state performs a veiled mechanism of 'policing' the Canadian border from the outside and curtailing the movements of Vincentian workers once they are inside the Canadian borders. One participant recalled a phone conversation from a referee about his location after leaving a farm on his day off. The fact that the referee is not the liaison, not a government official of the Ministry of Labour, and lives in St. Vincent and the Grenadines illustrate the core of workers' regulation by the source country. These monitoring means imply workers' return to the source country or at least decrease incidences of workers leaving the program and remaining in Canada. 
Policing the Canadian border and regulating workers by source country is embedded in the 'best -practiced "wins" of circular-managed migration discussed throughout the literature and in the introduction of this study. However, these 'wins' imposed by bilateral agreements truly benefits the receiving country and its farm employers. The workers under the SAWP suffer in terms of their freedom, workers' and human rights while the source country becomes further immersed in the labour migration patterns of dependency. In this study, Vincentian civil servants articulate the careful selection of "the best" workers for the program. The workers selected would be able to withstand the working conditions on Canadian farms without the need to rest after

"four/five hours in the sun... so that when the farmers see how hard the Vincentians work, they would request even more workers from St. Vincent and the Grenadines" (civil servant interviews).

Ideally, source countries participating in the SAWP should place more emphasis on fostering social and economic development in their own countries for their citizens, instead of the continuous cycle of exporting labour to reduce unemployment. However, with the realities of dependencies on global North countries for these states, it would be utopic to shun labour exportation as a means to reduce unemployment.

Identifying and choosing 'the best' workers starts with the recruitment process and the 'quality' of the referee in St. Vincent and the Grenadines. The Vincentian government, as well as other source countries, need to be cognizant of the implications of workers treatment when administering and maintaining circular migration programs such as SAWP. Canada is still ultimately responsible for providing a pathway for permanent residence. However, source countries through various roles are also culpable in maintaining the temporary nature of the program for SAWP workers. The omission of source countries roles in the discourse on the lack of transitionary pathways for Canadian permanent residency needs to be addressed in future research. 


\section{APPENDIX A: GENERAL PRINCIPLES OF SAWP}

\section{GENERAL PRINCIPLES FOR THE SEASONAL AGRICULTURAL WORKER PROGRAM}

This program operates on a Canadian First basis, which means, all employment opportunities for seasonal agricultural work in Canada are first made available to qualified Canadian citizens and permanent residents before recourse is made to the Seasonal Agricultural Worker Program (SAWP).

\section{GENERAL PRINCIPLES and OPERATIONAL GUIDELINES}

The programs will be administered in accordance with the following general principles and operational guidelines:

1. SAWP workers are to be authorized for employment in agricultural commodity sectors specified under the National List of SAWP Commodities during peak activity periods where the supply of Canadian workers is determined to be inadequate

2. The programs operate on a seasonal basis; and the term..." Seasonal basis" is understood to refer to both the worker and the work. Workers temporarily admitted to Canada under SAWP be given work terms exceeding 8 months duration. Employers can access SAWP from 01January to 15 December. It is to be clearly understood, by ALL parties, that every worker is to be repatriated by 15 December.

3. Caribbean and/or Mexican workers are to be provided with suitable accommodation that meet Provincial / Municipal housing standards, receive the prevailing approved rates of pay for the work involved, and are to be treated in a fair and equitable manner by the farm employers.

\section{NEW EMPLOYERS OR ADDITONAL WORKERS}

Employers requesting a higher number of workers than in the previous year will be assessed not only in the working conditions and factors considered in the Labour Market Impact Assessment (LMIA) process but also in relation to why the increase.

\section{TERMS AND CONDITIONS}

The terms and conditions, as well as program operations governing SAWP, have been negotiated by the Government of Canada, the government of Mexico, the governments of the participating Caribbean countries, and industry representatives. Employer's

request to participate in SAWP are subject to their acceptance of conditions set out in the employer/employee contract, the context of the LMIA, compliance with the Immigration and Refugee Protection Regulations in relation to TFWP and, in some instances, to their payment of a user-fee to F.A.R.M.S. who have been recognized by ESDC / Service Canada to perform an administrative role in program delivery. 


\section{EMPLOYMENT AGREEMENT}

The contract provides for employment of not less than 240 hours in a period of six weeks or less but NOT MORE THAN EIGHT MONTHS. In the case of workers who are transferred to another farm following completion of their contract, the 240 minimum hours of work DOES NOT apply.

\section{PERIODS OF EMPLOYMENT}

All participating commodities are required to maintain the following term of employment:

\section{January To 15 December}

\section{WAGES}

Employers are required to pay the greatest of:

i. the minimum agricultural or provincial wage rate;

ii. the prevailing SAWP rate as determined by E.S.D.C. / Service Canada

iii. or, the rate being paid by the employer to Canadian workers doing the same work.

\section{(i) SELECT COUNTRY}

Employers participating in the SAWP are responsible for selecting the source country from the Caribbean or Mexico.

\section{(ii) REQUESTS FOR FEMALE WORKERS}

Although most workers entering Canada under SAWP are male, all countries have requested to supply female seasonal agricultural workers, provided acceptable accommodation arrangements are available.

(iii) IMMIGRATION and REFUGEE PROTECTION ACT (IRPA) and the IMMIGRATION and REFUGEE PROTECTION REGULATIONS (IRPR)

Employment and Social Development Canada/Service Canada now have the authority to conduct inspections to verify an employer's compliance with the conditions in IRPR for a period of 6 years (refer to pg. 25). A Confidential Tip Line and a Complaints Web page is available to report abuse of a Foreign Worker. Each and every complaint will be reviewed by Integrity Services. 


\section{APPENDIX B: INTERVIEW QUESTIONS CIVIL SERVANTS}

\section{Ryerson}

University

350 Victoria St, Toronto, ON M5B 2K3

\section{Introduction. Purpose and Expectations}

Introduction will include telling participants the name and level of the program I am attached to at Ryerson and what the program entails.

After introducing myself as the interviewer, the following script will clarify the purpose and expectations of my research

"As part of the government organisation responsible for recruiting workers for the Canadian Seasonal Agriculture Worker Program or the Overseas Migrant Workers Program I am very grateful for you taking the time out of your day to sit down with me. You are assisting me in my research to include source countries voices in the Overseas Migrant Worker Program.

During the interview your perspective on the program and any text document you feel can contribute to my project is very much appreciated. Your response to the questions is essential for me to gain insight into the program from your perspective and I thank you for the contribution you are making to my project. An example of a question in our conversation could be telling me how you envision the program working for the people of St. Vincent and the Grenadines.

The interview will take approximately one hour.

\section{Confidentiality:}

The consent form that was provided to you outlined the purpose of the study, the risks, benefits, efforts to preserve confidentiality, my phone number and contact information, and appropriate time commitment associated with the interview. Your name will be kept separately from the transcription of this interview, and I will be using a coding system (Nvivo) to make sure that your identity is not connected to the transcripts and will be kept in a locked briefcase stored in my locked room while in St. Vincent. You will be given pseudo when the interviews are being transcribed, this will facilitate the deidentification of your identity when corresponding with my supervisor over email that might not be secure. At the end of the transcription and with the advice of my supervisor the identifying data of all participants will be destroyed by shredder. Your audio recording will also be destroyed during this time. 


\section{Questions:}

\section{Victoria St, Toronto, ON M5B 2K3}

1. How long have you been involved in this program?

2. What do you and your colleagues think about the program; its benefits for St. Vincent and its shortcomings or problems (if any)?

3. What challenges have you encountered? How have you tried to resolve them?

4. How competitive is it to secure contracts for the workers in St. Vincent and the Grenadines under the Overseas Migrant Worker Program? (this is the name by which the SAWP is known in St. Vincent and the Grenadines)

5. Do the workers have any mechanism available to return to work after being injured or taking some time off for reasons such as sickness of family?

6. What could the policy for returning to work look like? How could it be implemented?

7. On average what is the remittance dollar value within the past five years? Has the number of workers participating in the program increased in the past five years?

8. In regard to economic development (remittance, building St. Vincent --- more money to send the kids to school etc.) is there a difference whether the workers are able to move from being temporary or seasonal to being able to get Permanent Residence in Canada?

9. What kinds of agreements are there between the workers and your department in the Overseas Migrant Program? Would I be able to review these agreements?

10. What are the Standard Operating Procedures of the program between the government of St. Vincent and the Grenadines and the rest of the Organization of Eastern Caribbean States?

\section{Concluding questions:}

1) Are there any issues we have not talked about, but are relevant to the topic?

2) Is there anything else you would like to add?

\section{Closing:}

I would like to thank you for the time you have taken to answer my questions. If you are interested, I would be honored to provide you with a copy of my final project with your department. I will be sure to convey my gratitude to you in the acknowledgement of my research paper and any future publication that result from this research. Is there anything you would like to ask me about my project? 


\section{APPENDIX C: INTERVIEW QUESTIONS SAWP WORKERS}

\section{Ryerson}

University

350 Victoria St, Toronto, ON M5B 2K3

Introduction, Purpose and Expectations

Introduction will include telling participants the name and level of the program I am attached to at Ryerson and what the program entails.

After introducing myself as the interviewer, the following script will clarify the purpose and expectations of my research

"As a current/past worker in the Seasonal Agricultural Worker Program, I am very grateful for you taking the time out of your day to sit down with me. You are assisting me in my research to include St. Vincent and the Grenadines workers voices in the SAWP.

During the interview your response to the questions is essential for me to gain insight into the program from your perspective and I thank you for the contribution you are making to my project. An example of a question could be telling me how long you have been participating in the program"?

The interview will take approximately one hour.

\section{Confidentiality:}

The consent form that was provided to you outlined the purpose of the study, the risks, benefits, efforts to preserve confidentiality, my phone number and contact information, and appropriate time commitment associated with the interview. Your name will be kept separately from the transcription of this interview, and I will be using a coding system (Nvivo) to make sure that your identity is not connected to the transcripts and will be kept in a locked briefcase stored in my locked room while in St. Vincent. You will be given pseudo when the interviews are being transcribed, this will facilitate the deidentification of your identity when corresponding with my supervisor over email that might not be secure. At the end of the transcription and with the advice of my supervisor the identifying data of all participants will be destroyed by shredder. Your audio recording will also be destroyed during this time. 


\section{Questions:}

\section{Victoria St, Toronto, ON M5B 2K3}

1) How long have you been participating in the program?

2) What do you generally think about the program? In what ways are you satisfied?

3) Have you or other worker in the program experienced or observed any problems with the program?

4) What do your family think about the program; pros and cons?

5) How do you feel about a return to work policy should you get sick while working or your family member get sick while you are in Canada?

6) Do you see the government of St. Vincent playing an active part in helping you to transition to permanent residence in Canada? What do they do in this respect?

7) Or, do you see the government blocking you from transitioning? How?

8) What part do you believe the Canadian government plays in you being able to become a permanent residence through the program?

9) Do you believe the government of Canada, St. Vincent, or the farmers would agree to such a policy? why? why not?

10) Do you want the program to allow you to apply for permanent residence? Why? Why Not?

\section{Concluding questions:}

1) Are there any issues that you think I should have asked about during this interview?

2) Is there anything else you would like to add that I have missed?

\section{Closing:}

I would like to thank you for the time you have taken to answer my questions, and I appreciate you reliving some of your memories of the program with me.

I will be sure to convey my gratitude to you in the acknowledgement of my research paper and any future publication that result from this research.

Is there anything you would like to ask me about my project? 


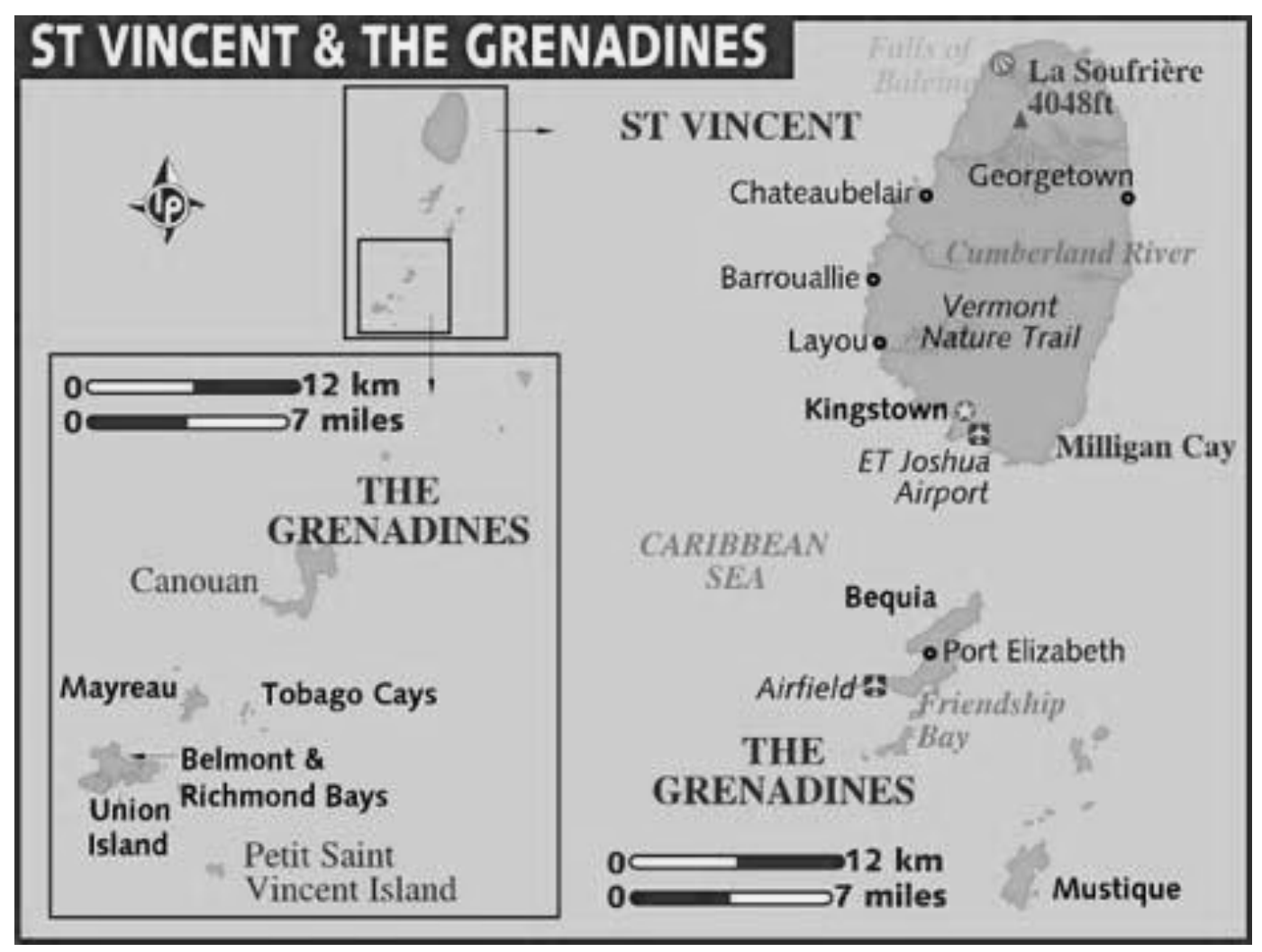

Figure 1 Map of St. Vincent and the Grenadines. Source: Gabisworld.com retrieved: http://gabisworld.com/photo/countries/saint-vincent-and-the- grenadines/07/ 


\section{REFERENCES:}

Andre, I. (1990). The genesis and persistence of the Commonwealth Caribbean Seasonal Agricultural Workers Program in Canada. Osgoode Hall Law Journal, 28(2), 243

Asomah, J. Y. (2014). Understanding the role of the state in promoting capitalist accumulation: A case study of the Canadian Seasonal Agricultural Worker Program. Canadian Graduate Journal of Sociology and Criminology, 3(2), 117-133.

Basok, T. (2000). He came, he saw, he stayed. guest worker programmes and the issue of NonReturn. International Migration, 38(2), 215-238

Basok, T. (2007). Canada's temporary migration program: A model despite flaws. Migration Information Source, Migration Policy Institute. Retrieve from Migration Policy Institute website: https:/www.migrationpolicy.org/article/canadas-temporary-migration-programmodel-despite-flaws

Bauder, H. (2008). Foreign farm workers in Ontario (Canada): Exclusionary discourse in the newsprint media. The Journal of Peasant Studies, 35(1), 100-118

Beckford, C. (2016). The experiences of Caribbean migrant farmworkers in Ontario, Canada. Social and Economic Studies, 65(1), 153-222.

Berger, R. (2015). Now I see it, now I don't: Researcher's position and reflexivity in qualitative research. Qualitative Research, 15(2), 219-234.

Brickner, R. K., \& Straehle, C. (2010). The missing link: Gender, immigration policy and the live-in caregiver program in Canada. Policy and Society, 29(4), 309-320

Canada. Citizenship and Immigration Canada. (2009). Discover Canada: The rights and responsibilities of citizenship, study guide. Discover Canada 
(2014). Discover Canada: The rights and responsibilities of citizenship (2014th ed.) Citizenship and Immigration Canada

Canadian Agricultural Human Resource Council. (2017). A review of Canada's Seasonal Agriculture Worker Program. Online: cahrc-ccrha.ca. Retreived from website: https://cahrc-ccrha.ca/sites/default/files/Emerging-Issues-

Research/A\%20Review\%20of\%20Canada\%27s\%20SAWP-Final.pdf

Canadian Labour Congress. (2016). Standing Committee on Human Resources, Skills and Social Development and the Status of Persons with Disabilities (HUMA) Review of the Temporary Foreign Worker Program (TFWP). Retrieved from Canada Labour Congress website:

http://www.ourcommons.ca/Content/Committee/421/HUMA/Brief/BR8360140/brexternal/CanadianLabourCongress-e.pdf

Castles, S., \& Miller, M.J. (2009). The Age of Migration: International Population Movements in the Modern World. New York: Palgrave Macmillan.

Castles, S., \& Ozkul, D. (2014). Circular Migration: Triple Win, or a New Label for Temporary Migration? Global \& Asian Perspectives on International Migration, 27. doi:10.1007/9783-319-08317-9_2

Constant, A. F., \& Zimmermann, K. F. (2010). Circular and repeat migration: Counts of exits and years away from the host country. Population Research and Policy Review, 30(4), 495515.

Creswell, J. W. (2014). Research design: Qualitative, quantitative, and mixed methods approaches (4th ed.). Chapter 1. Thousand Oaks: SAGE Publications

Dias-Abey, M. (2017). Justice on Our Fields: Can ‘Alt-Labor’ Organizations Improve Migrant Farm Workers' Conditions. Harvard Civil Rights-Civil Liberties Law Review, 53, 1-33 
Digital, VP. (2016) "St. Lucia Represented at Canadian/Caribbean Seasonal Agricultural Workers' Programme." Online website: St. Lucia News from The Voice St. Lucia, retrieved from thevoiceslu.com/2016/12/st-lucia-represented-canadiancaribbean-seasonalagricultural-workers-programme/.

Elgersma, S. (2014). Temporary Foreign Workers (Background Paper). Ottawa: Library of Parliament

F.A.R.M.S (2018). "Question and Answers." Retrieved from F.A.R.M.S. website: http://farmsontario.ca/pages.php?_ID=7

(2019). "Participating Countries." Retreived from

http://farmsontario.ca/countries.php?divname=EasternCaribbean

Go, A., Douglas, D., \& Konanur, S. (2019). One step forward for migrant workers but more to be done. The Toronto Star. Retreived from https://www.thestar.com/opinion/contributors/2019/02/05/one-step-forward-for-migrantworkers-but-more-to-be-done.html

Government of Saskatchewan. (2018). Saskatchewan Immigrant Nominee Program (SINP). "Semi-skilled Agriculture Worker with Existing Work Permit." Retrieved from https://www.saskatchewan.ca/residents/moving-to-saskatchewan/immigrating-tosaskatchewan/saskatchewan-immigrant-nominee-program/applicants-with-saskatchewanexperience/agriculture-worker.

Hennebry, J. (2012). Permanently temporary? agricultural migrant workers and their integration in Canada Institute for Research on Public Policy

Hennebry, J. L., \& Preibisch, K. (2012). A model for managed migration? re-examining best practices in Canada's Seasonal Agricultural Worker Program. International Migration, $50(\mathrm{~s} 1), \mathrm{e} 19$ 
Hugo, G. (2013). What we know about Circular Migration and Enhanced Mobility. Retrieved from Migration Policy Institute website: https://www.migrationpolicy.org/pubs/CircularMigration.pdf

IRCC. (2017). “Temporary residents.” Retreived from https://www.canada.ca/en/immigrationrefugees-citizenship/corporate/publications-manuals/operational-bulletinsmanuals/temporary-residents.html

IRCC. (2019). “Temporary Workers.” Retreived from https://www.canada.ca/en/immigrationrefugees-citizenship/corporate/publications-manuals/operational-bulletinsmanuals/temporary-residents/foreign-workers.html

Johnson González, B. (2016). Anthony Mann's border incident, the bracero program, and the government procedural. Diálogo: An Interdisciplinary Journal Published by the Center for Latino Research at DePaul University, 19(2), 69.

Kelley, N., \& Trebilcock, M. J. (2010). The making of the mosaic: A history of Canadian immigration policy (2nd ed.). Toronto: University of Toronto Press

Kestler-D'Amours, J. (2016). Canada: Foreign farm workers demand permanent status. Aljazeera News. Retreived from https://www.aljazeera.com/indepth/features/2016/09/canada- foreign-farm-workersdemand-permanent-status-160910125725983.html

Lemieux, T., Nadeau, J., Canada. Office of the Parliamentary Budget Officer, \& Canadian Electronic Library (Firm). (2015). Temporary foreign workers in Canada: A look at regions and occupational skill. Ottawa, Ontario: Canadian Electronic Library

Lu, Y., Hou, F. (2017). Transition from temporary foreign workers to permanent residents, 1990 to 2014. Ottawa, ON, CA: Statistics Canada 
Melancon, C.G., Grenier, G. (2015). Migrant agricultural workers and labour relations in Quebec. Labour Rights and Organizing Strategies. Conference on: Temporary Migrant Workers. Retreived from http://mcgradylaw.ca/pdfs/Conference $\% 20$ on $\% 20$ Temporary\%20Migrant $\% 20$ Workers.p df

Molnar, Petra. "Canada’s Temporary Foreign Worker Programs". The Canadian Encyclopedia, 26 January 2018, Historica Canada. Retrieved from https://www.thecanadianencyclopedia.ca/en/article/canadas-temporary-foreign-workerprograms. Accessed 25 March 2019.

O’Brien, R. (2014). “Global labour policy”. In N. Yeates (Ed.), Understanding global social policy (Chapter 6). Bristol, UK: The Policy Press

O'Keefe, D. (2009). 'Harper in denial at G20: Canada has 'no history of colonialism.' Website Rabble.ca. Retreived from http://rabble.ca/blogs/bloggers/derrick/2009/09/harper-denialg20-canada-has-no-history-colonialism

Ontario (Attorney General) v. Fraser, 2011 SCC 20

Perry, J. A. (2012). Barely legal: Racism and migrant farm labour in the context of Canadian multiculturalism. Citizenship Studies, 16(2), 189-201

Piper, N., Rosewarne, S., \& Withers, M. (2017). Migrant precarity in Asia: "Networks of Labour Activism" for a rights-based governance of migration. Development and Change,48(5), 1089-1110

Ruhs, M. (2016). The rights of migrant workers: Economics, politics and ethics. International Labour Review,155(2), 281-296 
Satzewich, V (1991) Racism and the Incorporation of Foreign Labour: Farm Labour Migration to Canada Since 1945. London: Routledge

Satzewich, V. (2007). Business or bureaucratic dominance in immigration policymaking in Canada: Why was Mexico included in the Caribbean Seasonal Agricultural Workers Program in 1974? Journal of International Migration and Integration / Revue De l'Integration Et De La Migration Internationale, 8(3), 255-275.

Satzewich, V. (2015). Points of entry: How Canada's immigration officers decide who gets in. Vancouver [British Columbia]: UBC Press

Silverman, S. J., \& Hari, A. (2016). Troubling the fields: Choice, consent, and coercion of Canada's seasonal agricultural workers. International Migration, 54(5), 91-104

Skeldon, R. (2012). Going Round in Circles: Circular migration, poverty alleviation and marginality. International Migration, 50(3), 43-60

Smart, J. (1998). Borrowed men on borrowed time: Globalization, labour migration and local economies in Alberta. Canadian Journal of Regional Science, 20(1-2), 141

Smith, A. A. (2015). Troubling "Project Canada": The caribbean and the making of "unfree migrant labor". Canadian Journal of Latin American and Caribbean Studies / Revue Canadienne Des Études Latino-Américaines Et Caraïbes, 40(2), 274-293

Stebbins, R. A. (2001). Exploratory Research in the Social Sciences. California: Sage Publications.

Vertovec, S. (2007). Circular migration: the way forward in global policy? International Migration Institute. Retrieved from https://ora.ox.ac.uk/objects/uuid:384d9c36-cc2e-43c59048-2ea72f179342 
Vosko, L. (2016). Blacklisting as a modality of deportability: Mexico's response to circular migrant agricultural workers' pursuit of collective bargaining rights in British Columbia, Canada. Journal of Ethnic and Migration Studies 42(8): 1371-87

(2018). Legal but Deportable: Institutionalized Deportability and the Limits of Collective Bargaining among Participants in Canada's Seasonal Agricultural Workers Program. International Law Review.

World Bank. (2006). Pacific Islands at home and away: expanding job opportunities for Pacific islanders through labor mobility (English). Washington, DC: World Bank. http://documents.worldbank.org/curated/en/158921468099585796/Pacific-Islands-athome-and-away-expanding-job-opportunities-for-Pacific-islanders-through-labormobility

WorldAtlas.com (2017). What type of government does St. Vincent and the Grenadines have? Politics: World Atlas.com retreived from https://www.worldatlas.com/articles/whattype- of-government-does-saint-vincent-and-the-grenadines-have.html

Wright, T (2018). Minister urged to press Jamaica over wage deductions of migrant workers in Canada. The National Post. Retreived from https://nationalpost.com/pmn/news$\mathrm{pmn} /$ canada-news-pmn/minister-urged-to-press-jamaica-over-wage-deductions-ofmigrant-workers-in-Canada 